\title{
Molekularne podłoże chorób spowodowanych mutacjami w genach kodujących podjednostki syntazy ATP
}

\section{Emilia Baranowska}

\section{Joanna Rytka}

\section{Róża Kucharczyk}

Zakład Genetyki, Instytut Biochemii i Biofizyki Polskiej Akademii Nauk, Warszawa

Zakład Genetyki, Instytut Biochemii i Biofizyki Polskiej Akademii Nauk, ul. Pawińskiego 5A, 02-106 Warszawa; tel.: (22) 59 21 221, e-mail: roza@ibb.waw.pl

Artykuł otrzymano 13 kwietnia 2018 r. Artykuł przyjęto 27 maja $2018 \mathrm{r}$.

Słowa kluczowe: syntaza ATP, gen ATP12, gen $A T P 6$, gen $A T P 8$, choroby mitochondrialne

Wykaz skrótów: OXPHOS - fosforylacja oksydacyjna; mtDNA - mitochondrialny DNA; nDNA - jądrowy DNA; IMM - wewnętrzna błona mitochondrialna; IMS - przestrzeń międzybłonowa; $\mathrm{P}_{\mathrm{i}}$ - fosforan nieorganiczny; ROS (ang. reactive oxygen species) - reaktywne formy tlenu; ATP - adenozynotrójfosforan; ADP adenozynodwufosforan; $\mathrm{CH}$ - chloroheksydyna; NaPT - pirytion sodu

Podziękowania: Praca powstała w trakcie realizacji projektu badawczego NCN DEC-2016/23/B/NZ3/02098, finansowanego ze środków przyznanych przez Narodowe Centrum Nauki. Analiza efektów mutacji in silico wykonana została we współpracy z dr A. Dautant z IBGC i profesorem J.P. di Rago z IBGC, CNRS, Bordeaux.

\section{STRESZCZENIE}

$S^{3}$ jednostki enzymu (17 białek), prowadzą do chorób neurodegeneracyjnych. Dwie podjednostki tego enzymu, 8 (ATP8, inna nazwa A6L) i a (ATP6), kodowane są w genomie mitochondrialnym przez geny MT-ATP8 i MT-ATP6. 17 mutacji związanych z chorobami zidentyfikowano w pięciu genach jądrowych kodujących podjednostki enzymu. 58 mutacji zostało opisanych w genach MT-ATP8 i MT-ATP6, $36 \mathrm{z}$ nich zostało zdeponowanych w bazie danych MITOMAP. Dla większości z nich zarówno patogenny charakter jak i mechanizm choroby nie są znane. $W$ tej pracy podsumowujemy aktualną wiedzę na temat molekularnych podstaw chorób spowodowanych nieprawidłowym funkcjonowaniem syntazy ATP. Opisujemy mutacje w genach kodujących podjednostki enzymu oraz dane biochemiczne uzyskane w badaniach komórek pacjentów, modeli komórkowych i drożdżowych, a ponadto badania wykorzystujące drożdże mające na celu selekcję leków i poznanie ich mechanizmu działania. Mutacje w podjednostkach 8 i a wprowadziliśmy do ostatnio opublikowanej struktury domeny błonowej enzymu i dyskutujemy ich strukturalne i funkcjonalne konsekwencje.

\section{WPROWADZENIE}

Mitochondria to organelle otoczone dwiema warstwami błony, rozdzielonymi przestrzenią międzybłonową (IMS). Błony otaczają macierz mitochondrialną. Błona wewnętrzna tworzy wpuklenia do wnętrza macierzy, tzw. grzebienie. Mitochondria mają własny genom i własny system syntezy białek. Kolista cząsteczka ludzkiego mtDNA długości 16569 par zasad koduje 37 genów: 22 tRNAs, 2 rRNAs i 13 białek. Wielkość, kształt i liczba mitochondriów w komórce jest różna, zależna od organizmu, a w obrębie jednego organizmu zależy od specjalizacji komórki/tkanki. Najważniejszą funkcją mitochondriów jest synteza komórkowej energii w formie ATP na drodze fosforylacji oksydacyjnej (OXPHOS), przeprowadzanej przez kompleksy łańcucha oddechowego [1]. System OXPHOS buduje 77 białek kodowanych w jądrowym DNA (nDNA) i 13 białek kodowanych w mitochondrialnym DNA (mtDNA). Białka te są osadzone w wewnętrznej błonie mitochondrialnej (IMM), wchodzą w skład czterech wielopodjednostkowych kompleksów (I-IV) oraz syntazy ATP [2]. Elektrony pochodzące $\mathrm{z}$ utleniania metabolitów przenoszone są na tlen, co prowadzi do uwalniania energii koniecznej do pompowania protonów z macierzy mitochondrialnej do przestrzeni międzybłonowej. Skutkiem tego procesu jest utworzenie elektrochemicznego gradientu protonów w poprzek błony, nazywanego siłą motoryczną, gdzie zewnętrzna strona IMM jest naładowana dodatnio a wewnętrzna ujemnie. Syntaza ATP wykorzystuje ten gradient do produkcji ATP z ADP i nieorganicznego fosforanu (Pi) [3]. Mitochondria, obok ich głównej funkcji, jaką jest synteza komórkowej energii w formie ATP, pełnią szereg innych funkcji istotnych dla wzrostu i różnicowania komórek czy regulacji cyklu komórkowego. Są to synteza aminokwasów, lipidów, hemu czy mostków żelazowo-siarkowych, utrzymanie homeostazy jonów wapnia czy indukcja apoptozy. Oksydacyjnej fosforylacji towarzyszy produkcja reaktywnych form tlenu (ROS), które są bardzo ważne w przekazywaniu sygnałów w komórce. Zaburzenie którejkolwiek z funkcji mitochondriów prowadzi do chorób zwanych chorobami mitochondrialnymi.

\section{CHOROBY MITOCHONDRIALNE}

Choroby mitochondrialne należą do chorób o podłożu genetycznym, spowodowane są mutacjami zarówno w nDNA jak i w mtDNA [4]. Mutacje w mtDNA to delecje, rearanżacje oraz mutacje punktowe $\mathrm{w}$ genach kodujących rRNA, tRNA czy białka kompleksów oddechowych (8 u Saccharomyces cerevisiae, 13 u ludzi). Mutacje jądrowe występują zarówno w genach kodujących podjednostki kompleksów łańcucha oddechowego, jak i czynniki niezbędne do ich prawidłowego składania w błonie. Ich efektem jest nieprawidłowe 


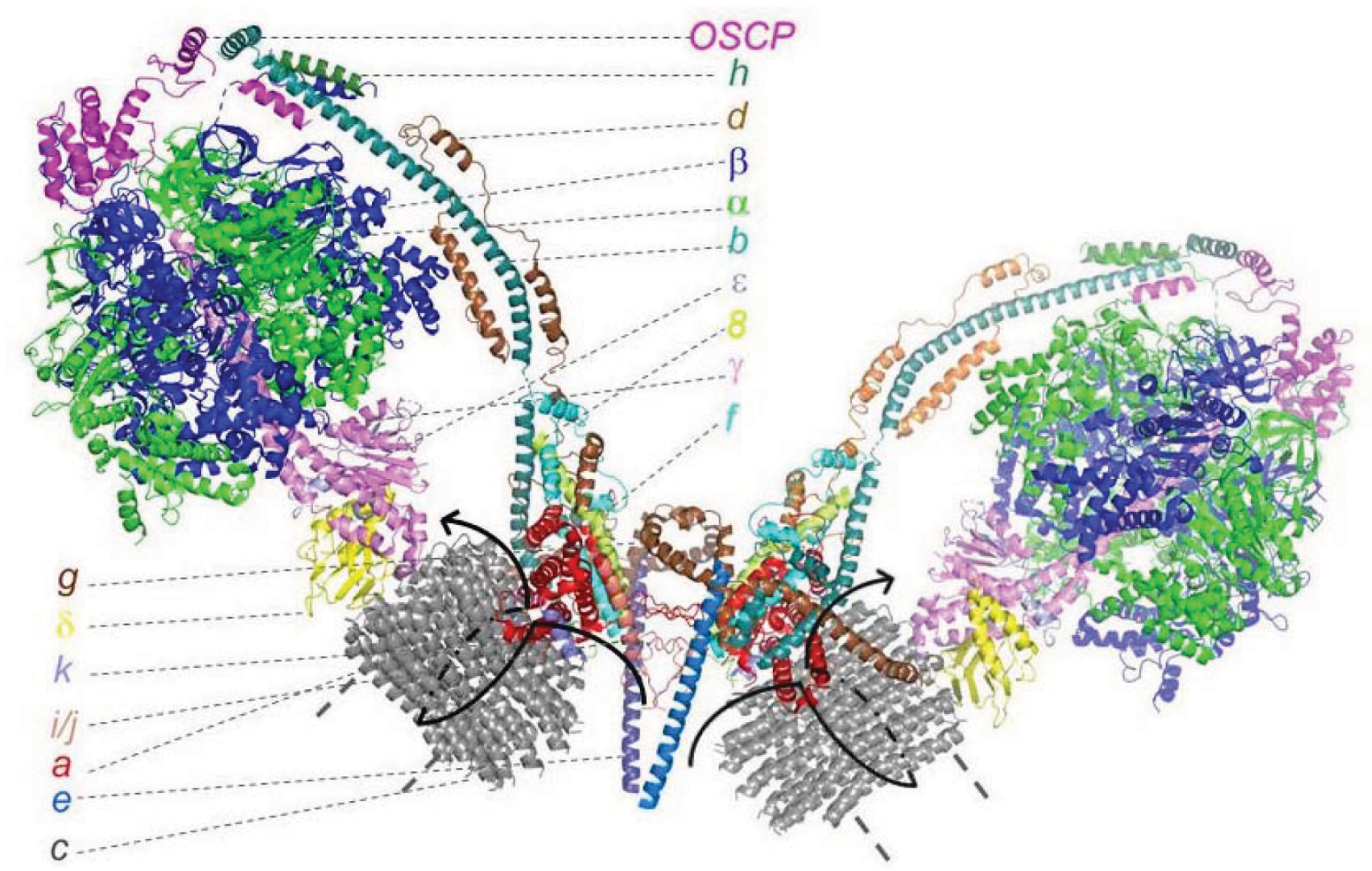

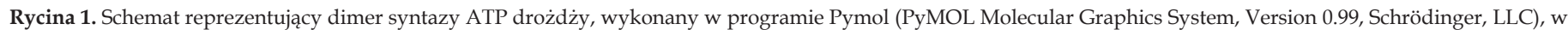

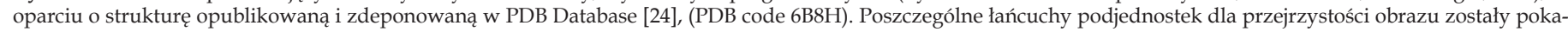
zane na jednym monomerze. Krawędzie zakrzywionej błony zaznaczono linią przerywaną a drogę protonów linią ciągłą.

działanie mitochondriów, także systemu OXPHOS, co leży u podstaw ponad 150 zdefiniowanych chorób genetycznych [5-10], występujących z częstością 1 na 4300 osób dorosłych [11]. Dotyczą one organów i tkanek o wysokim zapotrzebowaniu na energię. Typowe objawy kliniczne obejmują wady słuchu/wzroku, encefalopatię, choroby serca, układu mięśniowo-nerwowego, ataksje, zaburzenia metaboliczne, funkcji wątroby, nerek czy gruczołów dokrewnych, często towarzyszy im cukrzyca [1214]. Około $15 \%$ przypadków spowodowanych jest mutacjami w mtDNA, co wynika $\mathrm{z}$ narażenia tego DNA na mutacje z powodu bezpośredniego kontaktu ze źródłem ROS oraz z niskiej wydajności systemu naprawy w mitochondriach [15]. W różnych jednostkach chorobowych opisano ponad 600 mutacji mtDNA, w tym delecje dużych jego fragmentów i rearanżacje genomu [16]. Pomimo wielu charakterystycznych objawów defektów funkcji mitochondriów, diagnoza tych chorób jest trudna, z powodu ich dużej różnorodności i nasilenia, zależnych od rodzaju mutacji. Występowanie mtDNA w tysiącach kopii na komórkę, w stanie homoplazmatycznym (wszystkie kopie o jednakowej sekwencji) jak i heteroplazmatycznym (kopie mtDNA różniące się pomiędzy sobą, np. na skutek mutacji, występujące $\mathrm{w}$ różnych proporcjach) [9] oraz dziedziczenie po linii matki są jedną z przyczyn różnorodności fenotypowej. Minimalny poziom zmutowanego mtDNA powodujący chorobę to $60 \%$, jest on często różny w różnych tkankach [9]. Przebieg choroby jest zróżnicowany, nawet w przypadku chorób powodowanych przez tę samą mutację, zależy bowiem od stopnia heteroplazmii i innych czynników genetycznych, w tym haplogrupy mtDNA czy towarzyszącym mutacjom.

Badania prowadzone $\mathrm{w}$ naszym zespole skoncentrowane są na poznaniu molekularnego podłoża chorób wynikających z mutacji w mtDNA w genach MT-ATP8 i MT-ATP6 (ATP8 i ATP6 w dalszej części artykułu), kodujących podjednostki syntazy ATP.

\section{SRUKTURA I FUNKCJONOWANIE SYNTAZY ATP}

Syntaza ATP zlokalizowana jest w błonie wewnętrznej mitochondriów. Buduje ją 17 białek tworzących domenę błonową $\mathrm{F}_{\mathrm{O}} \mathrm{i}$ katalityczną $\mathrm{F}_{1}$ połączonych ramieniem centralnym i zewnętrznym (Ryc. 1, Tab. 1) [17-19]. Skierowaną do macierzy domenę katalityczną $\mathrm{F}_{1}$ tworzy heksamer podjednostek $(a \beta)_{3}$. Ramię centralne, złożone z podjednostek $\gamma \delta \varepsilon$, łączy się z centrum domeny katalitycznej poprzez podjednostkę $\gamma$. Domenę $\mathrm{F}_{\mathrm{O}}$ tworzy osiem podjednostek $c$ u człowieka, a 10 podjednostek Atp9 u drożdży wraz z podjednostką a (Atp6), pomiędzy którymi następuje transport protonów przez membranę podczas procesu katalizy. Dodatkowo $\mathrm{W}$ skład domeny Fo wchodzą małe podjednostki: 8 (ATP8, alias $\mathrm{A} 6 \mathrm{~L}), f, 6.8 \mathrm{PL}$ (i/j u drożdży), które wraz z podjednostkami $b$ (Atp4 u drożdży), $d$, F6 ( $h$ u drożdży), oraz OSCP tworzą ramię zewnętrzne. Trzy podjednostki $e, g$, DAPIT ( $k$ u drożdży), stabilizują dimery syntazy ATP [20,21], które 


\begin{tabular}{|c|c|c|c|}
\hline Człowiek & & S. cerevisiae & \\
\hline Gen & Podjednostka & Gen & Podjednostka \\
\hline АТР5A1 & $a$ & ATP1 & $a$ \\
\hline ATP5B & $\beta$ & ATP2 & $\beta$ \\
\hline ATP5C1 & $r$ & ATP3 & $r$ \\
\hline ATP5D & $\delta$ & ATP16 & $\delta$ \\
\hline ATP5E & $\varepsilon$ & ATP15 & $\varepsilon$ \\
\hline ATP5F1, & $b$ & ATP4 & 4 lub $b$ \\
\hline ATP5G1, ATP5G2, ATP5G3 & $c 1, c 2, c 3^{*}$ & ATP9 & 9 lubc \\
\hline AТР5H & $d$ & ATP7 & $d$ \\
\hline ATP5I & $e$ & ATP21 lub TIM11 & $e$ \\
\hline ATP5J & F6 & ATP14 & $h$ \\
\hline ATP5J2 & $f$ & ATP17 & $f$ \\
\hline ATP5L & $g$ & ATP20 & $g$ \\
\hline ATP5O & OSCP & ATP5 & 5 lub OSCP \\
\hline MT-ATP6 & $a$ lub ATP6 & ATP6 & a lub Atp6 \\
\hline MT-ATP8 & 8, ATP8 lub A6L & ATP8 & 8 lub Atp8 \\
\hline C14orf2 & 6,8 PL & ATP18 & $i$ lub $j$ \\
\hline USMG5 & DAPIT & ATP19 & $k$ \\
\hline
\end{tabular}

*Podjednostki c1, c2, c3, kodowane są przez trzy różne geny; różnią się jedynie sekwencją sygnałową kierującą do mitochondriów, która jest odcinana po dotarciu białka do błony wewnętrznej. katalityczna $\beta$ przechodzi trzy stany konformacyjne, pozwalające na związanie ADP i $P_{i}$ i syntezę ATP zgodnie z mechanizmem zaproponowanym przez Petera Boyera [3]. Syntaza ATP może również hydrolizować ATP, wówczas protony transportowane są z macierzy do przestrzeni międzybłonowej.

\section{MODELE DROŻDŻOWE \\ I KOMÓRKOWE MUTACJI W GENACH MITOCHONDRIALNYCH SYNTAZY ATP}

Aby prawidłowo sklasyfikować mutację potrzeba wielu danych, np. informacji o rodzinnej historii choroby, stopniu hetreoplazmii i jego korelacji z objawami choroby, czy danych biochemicznych o aktywności zmutowanego enzymu i o jego strukturze. Ze względu na heteroplazmię mtDNA u człowieka oraz występowanie $\mathrm{w}$ nim polimorfizmów $\mathrm{w}$ populacji, trudno jest sklasyfikować daną mutację jako patologiczną. Dane biochemiczne uzyskane na komórkach czy tkankach pacjentów nie pozwalają na określenie skutków pojedynczej mutacji. Dodatkowo, efekt mutacji może być wzmocniony poprzez występowanie jednocześnie innych mutacji, także w genomie jądrowym [29,30]. Mimo tych trudności badania bezpośrednio na komórkach czy tkankach od pacjentów pokazały jaki poziom nieprawidło-

usytuowane wzdłuż błony prowadzą do jej wygięcia i tworzenia grzebieni $[22,23]$.

Syntaza ATP wykorzystuje gradient protonów na błonie wewnętrznej, które w procesie syntezy ATP przedostają się do macierzy poprzez kanał utworzony przez hydrofilowe aminokwasy podjednostek $c$ i $a$, powodując rotację pierścienia. Wraz $\mathrm{z}$ pierścieniem rotują podjednostki ramienia centralnego. W centrum błony, protony są wiązane do zachowanej w ewolucji reszty kwaśnego aminokwasu w drugiej helisie podjednostki $c(c \mathrm{H} 2)(c \mathrm{E} 58$ u H. sapiens, cE59 u drożdży), zlokalizowanej na zewnętrznej powierzchni pierścienia. Przyjęto, że związanie protonu do grupy karboksylowej kwasu glutaminowego (E) niszczy oddziaływanie elektrostatyczne pomiędzy nią a naładowaną dodatnio, zachowaną w ewolucji resztą argininy w podjednostce $a \mathrm{w}$ helisie $5(a \mathrm{H} 5)$ ( $a \mathrm{R} 159$ u H. sapiens, aR186 u drożdży) [24-27]. Argininie przypisuje się funkcję elektrostatycznego separatora pomiędzy ścieżką dla protonów napływających z IMS do środka błony a drugą ścieżką, którą protony, po przejściu pełnego obrotu pierścienia, przedostają się do macierzy [28]. Uzyskanie dokładnej struktury syntazy ATP drożdży dostarczyło wielu informacji na temat budowy kanału dla protonów [24]. Wielkość hydrofilowej kieszeni, tworzącej kanał po stronie macierzy, to około $15 \AA$. Arginina aR186 skierowana jest do jej środka, a jej „ścianki” tworzą reszty polarnych aminokwasów helisy $a \mathrm{H} 5$ (u drożdży S250, Y251, K253, D254, H259) i aH6 (u drożdży E172, S175, R179, S182), spośród których E172 oraz D254 zostały zachowane w ewolucji; proponuje się, że reszty te biorą bezpośredni udział w transporcie protonów [24]. Na skutek rotacji pierścienia i ramienia centralnego podjednostka wego funkcjonowania systemu OXPHOS prowadzi do rozwoju choroby.

W celu zbadania efektów pojedynczej mutacji wykorzystuje się modele homoplazmatycznych linii komórkowych, cybrydy [31]. Takie linie udało się otrzymać dla jedenastu mutacji w genie ATP6 [32-44]. Inne podejście to wykorzystanie komórek drożdży $S$. cerevisiae, których kompleksy systemu OXPHOS, także syntaza ATP, wykazują wysokie podobieństwo do kompleksów OXPHOS w mitochondriach ludzkich [45-49]. Drożdże S. cerevisiae są organizmem, w którym jest możliwa ukierunkowana mutageneza mtDNA. Metodą biolistyczną wprowadza się do mitochondriów syntetyczny DNA kodujący zmutowaną wersję genu. Taki gen na drodze rekombinacji łatwo wprowadzić do kompletnego genomu mitochondrialnego [50]. Drożdże nie tolerują stanu heteroplazmii, zatem zawsze otrzymuje się komórki homoplazmatyczne [51]. Dzięki zdolności do fermentacji glukozy komórki drożdży są żywotne nawet kiedy system OXPHOS nie funkcjonuje [52-54].

Na modelu drożdżowym bada się wzrost zależny od oddychania komórkowego, stabilność mtDNA, morfologię mitochondriów, zużycie tlenu przez wyizolowane mitochondria, efektywność syntezy i hydrolizy ATP, poziom potencjału na wewnętrznej błonie mitochondriów, stan złożenia/stabilność syntazy ATP oraz poziom syntezy białek kodowanych mitochondrialnie. Skonstruowane mutanty $\mathrm{w}$ mtDNA S. cerevisiae wykorzystaliśmy do zbadania efektu dziewięciu mutacji w genie ATP6 przypisanych określonym chorobom [36,53,55-62]. 


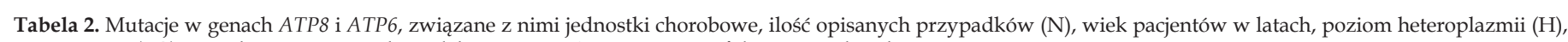
patogenność (PG) oraz aktywność i stan kompleksu syntazy ATP wraz z morfologią mitochondriów.

\begin{tabular}{|c|c|c|c|c|c|c|c|c|c|c|}
\hline $\begin{array}{l}\text { Mutacja w } \\
\text { mtDNA }\end{array}$ & $\begin{array}{l}\text { Substytucja } \\
\text { reszty amino- } \\
\text { kwasowej } \\
\text { w białku }\end{array}$ & Jednostka chorobowa & $\mathrm{N}$ & $\begin{array}{l}\text { Wiek } \\
\text { (w latach) }\end{array}$ & $\begin{array}{l}\mathrm{H} \\
\%\end{array}$ & $\begin{array}{l}\text { Syntaza ATP } \\
\text { Aktywność }\end{array}$ & $\begin{array}{l}\text { Stan złożenia } \\
\text { enzymu }\end{array}$ & $\begin{array}{l}\text { ROS/ } \\
\text { morfologia } \\
\text { mitochondriów }\end{array}$ & Literatura & PG \\
\hline $\mathrm{m} .8381 \mathrm{~A}>\mathrm{G}$ & $8 \mathrm{~T} 6 \mathrm{~A}$ & MIDD, LVHT & 2 & 38,57 & 99 & $\mathrm{bd}$ & bd & bd/zaburzona & {$[71,72]$} & $\mathrm{N}$ \\
\hline $\mathrm{m} .8393 \mathrm{C}>\mathrm{T}$ & 8P10S & Padaczka & 1 & 10 & $<99$ & $\mathrm{bd}$ & bd & $\mathrm{bd} / \mathrm{bd}$ & [73] & $\mathrm{N}$ \\
\hline $\mathrm{m} .8403 \mathrm{~T}>\mathrm{C}$ & $8 \mathrm{I} 13 \mathrm{~T}$ & $\begin{array}{l}\text { Epizodyczna } \\
\text { niewydolność } \\
\text { mięśniowa }\end{array}$ & 1 & 8 & 99 & normalna & normalny & $\begin{array}{l}\text { podwyższone/ } \\
\text { bd }\end{array}$ & {$[42]$} & $\mathrm{N}$ \\
\hline $\mathrm{m} .8411 \mathrm{~A}>\mathrm{G}$ & $8 \mathrm{M} 16 \mathrm{~V}$ & $\begin{array}{l}\text { Choroba neurologiczna } \\
\text { ze ślepotą }\end{array}$ & $1 \dagger$ & 10 & 97 & $\mathrm{bd}$ & $\mathrm{bd}$ & $\mathrm{bd} / \mathrm{bd}$ & {$[74]$} & $\mathrm{N}$ \\
\hline $\mathrm{m} .8463 \mathrm{~A}>\mathrm{G}$ & $8 \mathrm{Y} 33 \mathrm{C}$ & Schizofrenia & 1 & bd & 100 & $\mathrm{bd}$ & bd & $\mathrm{bd} / \mathrm{bd}$ & [77] & $\mathrm{N}$ \\
\hline $\mathrm{m} . \underline{8472 \mathrm{C}>\mathrm{T}}$ & $8 \mathrm{P} 36 \mathrm{~L}$ & Autyzm & 3 & $4-8$ & 100 & $\mathrm{bd}$ & bd & $\mathrm{bd} / \mathrm{bd}$ & {$[78]$} & $\mathrm{N}$ \\
\hline $\mathrm{m} .8481 \mathrm{C}>\mathrm{T}$ & 8P39L & Tetralogia Fallota & 1 & 1 & 100 & bd & bd & $\mathrm{bd} / \mathrm{bd}$ & [75] & $\mathrm{N}$ \\
\hline $\mathrm{m} . \underline{8502 \mathrm{~A}>\mathrm{T}}$ & $8 \mathrm{~N} 46 \mathrm{I}$ & MTLE-HS & 40 & dorośli & $11-36$ & $\mathrm{bd}$ & bd & $\mathrm{bd} / \mathrm{bd}$ & {$[70]$} & $\mathrm{P}$ \\
\hline$\underline{\mathrm{m} .8510 \mathrm{~A}>\mathrm{G}}$ & $8 \mathrm{~K} 49 \mathrm{E}$ & Schizofrenia & 1 & bd & 100 & bd & bd & $\mathrm{bd} / \mathrm{bd}$ & [76] & $\mathrm{N}$ \\
\hline m.8519G >A & $8 \mathrm{E} 52 \mathrm{~K}$ & Schizofrenia & 1 & bd & 100 & $\mathrm{bd}$ & bd & $\mathrm{bd} / \mathrm{bd}$ & {$[77]$} & $\mathrm{N}$ \\
\hline $\mathrm{m} .8528 \mathrm{~T}>\mathrm{C}$ & $\begin{array}{l}\text { 8W55R } \\
a \mathrm{M} 1 \mathrm{~T}\end{array}$ & $\begin{array}{l}\text { Kardiomiopatia } \\
\text { dziecięca }\end{array}$ & $5,3+$ & $0.1-4$ & $90-98$ & obniżona & $\mathrm{bd}$ & $\mathrm{bd} / \mathrm{bd}$ & {$[79,80]$} & $\mathrm{P}$ \\
\hline m.8529G $>A$ & $\begin{array}{l}\text { 8W55X } \\
a \text { M1I }\end{array}$ & $\begin{array}{l}\text { Kardiomiopatia } \\
\mathrm{z} \text { neuropatią }\end{array}$ & 1 & 16 & 90 & obniżona & defektywny & $\mathrm{bd} / \mathrm{bd}$ & {$[44]$} & $\mathrm{P}$ \\
\hline $\mathrm{m} .8558 \mathrm{C}>\mathrm{T}$ & $\begin{array}{l}\text { 8P65S } \\
a \mathrm{~A} 11 \mathrm{~V}\end{array}$ & LVHC & 1 & 0.2 & bd & bd & bd & $\mathrm{bd} / \mathrm{bd}$ & [81] & $\mathrm{C}$ \\
\hline $\mathrm{m} .8561 \mathrm{C}>\mathrm{G}$ & $\begin{array}{l}8 \mathrm{P} 66 \mathrm{~A} \\
a \mathrm{P} 12 \mathrm{R}\end{array}$ & $\begin{array}{l}\text { Ataksja, neuropatia, } \\
\text { z cukrzycą }\end{array}$ & 2 & 59,64 & 99 & obniżona & defektywny & $\mathrm{bd} / \mathrm{bd}$ & [82] & $\mathrm{P}$ \\
\hline m.8527A $>G$ & $a \mathrm{M} 1 \mathrm{~V}$ & $\begin{array}{l}\text { Choroba neuro- } \\
\text { mięśniowa }\end{array}$ & 1 & 7 & $\mathrm{bd}$ & $\mathrm{bd}$ & $\mathrm{bd}$ & $\mathrm{bd} / \mathrm{bd}$ & [112] & $\mathrm{N}$ \\
\hline $\mathrm{m} .8597 \mathrm{~T}>\mathrm{C}$ & $a \mathrm{I} 24 \mathrm{~T}$ & MILS & 1 & 2 & 95 & $\mathrm{bd}$ & $\mathrm{bd}$ & $\mathrm{bd} / \mathrm{bd}$ & [128] & $\mathrm{N}$ \\
\hline m.8611insC & $a \mathrm{~L} 29 \mathrm{Pfs} X 36$ & Ataksja z encefalopatią & 1 & 4 & $60-80$ & obniżona & defektywny & bd/zaburzona & [105] & $\mathrm{P}$ \\
\hline m.8618insT & aT33HfsX32 & NARP & 1 & 40 & 85 & $\mathrm{bd}$ & defektywny & $\mathrm{bd} / \mathrm{bd}$ & [129] & $\mathrm{N}$ \\
\hline $\mathrm{m} .8668 \mathrm{~T}>\mathrm{C}$ & $a \mathrm{~W} 48 \mathrm{R}$ & LHON & 1 & dorosły & 99 & bd & $\mathrm{bd}$ & $\mathrm{bd} / \mathrm{bd}$ & [130] & $\mathrm{N}$ \\
\hline $\mathrm{m} . \underline{8684 \mathrm{C}>\mathrm{T}}$ & $a \mathrm{~T} 53 \mathrm{I}$ & $\begin{array}{l}\text { Autyzm } \\
\text { Niewydolność jajników } \\
\text { LHON }\end{array}$ & $\begin{array}{l}1 \\
7 \\
1\end{array}$ & $\begin{array}{l}4-8 \\
25 \\
\text { dorosły }\end{array}$ & 100 & bd & $\mathrm{bd}$ & $\mathrm{bd} / \mathrm{bd}$ & $\begin{array}{l}{[78,130,} \\
131]\end{array}$ & $\mathrm{N}$ \\
\hline m. $\underline{8697 \mathrm{G}>\mathrm{A}}$ & $a \mathrm{M} 57 \mathrm{I}$ & $\begin{array}{l}\text { Autyzm } \\
\text { LHON }\end{array}$ & 5 & $4-8$ & 100 & $\mathrm{bd}$ & bd & $\mathrm{bd} / \mathrm{bd}$ & {$[78,130]$} & $\mathrm{N}$ \\
\hline $\mathrm{m} \cdot \underline{8701 \mathrm{~A}>\mathrm{G}}$ & $a \mathrm{~T} 59 \mathrm{~A}$ & Autyzm & 1 & $4-8$ & 100 & $\mathrm{bd}$ & bd & $\mathrm{bd} / \mathrm{bd}$ & {$[78]$} & $\mathrm{N}$ \\
\hline m.8719G >A & $a \mathrm{G} 65 \mathrm{X}$ & Miopatia & 1 & $\mathrm{bd}$ & $<99$ & bd & bd & $\mathrm{bd} / \mathrm{bd}$ & [116] & $\mathrm{N}$ \\
\hline m. $8723 \mathrm{G}>\mathrm{A}$ & $a \mathrm{R} 66 \mathrm{Q}$ & Schizofrenia & 1 & bd & 100 & $\mathrm{bd}$ & bd & $\mathrm{bd} / \mathrm{bd}$ & [76] & $\mathrm{N}$ \\
\hline m. $8794 \mathrm{C}>\mathrm{T}$ & $a \mathrm{H} 90 \mathrm{Y}$ & Schizofrenia & 1 & bd & 100 & bd & bd & $\mathrm{bd} / \mathrm{bd}$ & [77] & $\mathrm{N}$ \\
\hline $\mathrm{m} .8836 \mathrm{~A}>\mathrm{G}$ & $a \mathrm{M} 104 \mathrm{~V}$ & $\begin{array}{l}\text { LHON } \\
\text { Autyzm }\end{array}$ & $\begin{array}{l}1 \\
3\end{array}$ & $\begin{array}{l}11 \\
4-8\end{array}$ & 100 & bd & bd & $\mathrm{bd} / \mathrm{bd}$ & {$[78,132]$} & $\mathrm{N}$ \\
\hline m. $8839 \mathrm{G}>\mathrm{C}$ & $a \mathrm{~A} 105 \mathrm{P}$ & NARP & 1 & 57 & $21-88$ & normalna & bd & $\mathrm{bd} / \mathrm{bd}$ & [34] & $\mathrm{P}$ \\
\hline m. $8843 \mathrm{~T}>\mathrm{C}$ & $a \mathrm{I} 106 \mathrm{~T}$ & Schizofrenia & 2 & $\mathrm{bd}$ & 100 & bd & $\mathrm{bd}$ & $\mathrm{bd} / \mathrm{bd}$ & {$[76,77]$} & $\mathrm{N}$ \\
\hline$m .8851 T>C$ & $a \mathrm{~W} 109 \mathrm{R}$ & FBSN & 2 & 3 & $87-99$ & obniżona & defektywny & bd/zaburzona & $\begin{array}{l}{[57,107,} \\
108]\end{array}$ & $\mathrm{P}$ \\
\hline m. $8890 A>G$ & $a \mathrm{~K} 122 \mathrm{E}$ & MS & 1 & 18 & $35-38$ & $\mathrm{bd}$ & bd & $\mathrm{bd} / \mathrm{bd}$ & [110] & $\mathrm{N}$ \\
\hline m. $8902 \mathrm{G}>\mathrm{A}$ & $a \mathrm{~A} 126 \mathrm{~T}$ & Schizofrenia & 1 & bd & 100 & bd & bd & $\mathrm{bd} / \mathrm{bd}$ & [76] & $\mathrm{N}$ \\
\hline$m .8932 C>T$ & $a \mathrm{P} 136 \mathrm{~S}$ & $\begin{array}{l}\text { Choroba neuro- } \\
\text { mięsniowa }\end{array}$ & 1 & 7 & 100 & obniżona & defektywny & $\mathrm{bd} / \mathrm{bd}$ & $\begin{array}{l}{[61,112,} \\
113]\end{array}$ & $\mathrm{P}$ \\
\hline m. $8945 \mathrm{~T}>\mathrm{C}$ & aM140T & Schizofrenia & 1 & bd & 100 & $\mathrm{bd}$ & bd & $\mathrm{bd} / \mathrm{bd}$ & [76] & $\mathrm{N}$ \\
\hline m.8950G >A & $a \mathrm{~V} 142 \mathrm{I}$ & LHON z dystonią & 1 & 23 & bd & obniżona & $\mathrm{bd}$ & $\mathrm{bd} / \mathrm{bd}$ & {$[133]$} & $\mathrm{N}$ \\
\hline$m .8969 G>A$ & $a S 148 N$ & $\begin{array}{l}\text { MLASA } \\
\text { Neuropatia }\end{array}$ & $\begin{array}{l}1 \\
1\end{array}$ & $\begin{array}{l}6 \\
14\end{array}$ & $60-90$ & obniżona & defektywny & $\begin{array}{l}\text { podwyższone/ } \\
\text { bd }\end{array}$ & $\begin{array}{l}{[106]} \\
{[36]}\end{array}$ & $\mathrm{C}$ \\
\hline m. $8989 \mathrm{G}>\mathrm{C}$ & $a \mathrm{~A} 155 \mathrm{P}$ & NARP & 1 & 53 & $33-94$ & obniżona & bd & $\mathrm{bd} / \mathrm{bd}$ & {$[36,103]$} & $\mathrm{P}$ \\
\hline$m .8993 T>G$ & $a \mathrm{~L} 156 \mathrm{R}$ & NARP/MILS & $\begin{array}{l}53 \\
10 \dagger\end{array}$ & $0.1-53$ & $13-99$ & obniżona & normalna & $\begin{array}{l}\text { podwyższone/ } \\
\text { zaburzona }\end{array}$ & $\begin{array}{l}{[37-41,62} \\
83,85-93 \\
134-139]\end{array}$ & C \\
\hline$m .8993 T>C$ & $a \mathrm{~L} 156 \mathrm{P}$ & NARP/MILS & $\begin{array}{l}35 \\
4 \dagger\end{array}$ & $0.1-77$ & $20-96$ & obniżona & defektywny & $\begin{array}{l}\text { podwyższone/ } \\
\text { normalna }\end{array}$ & $\begin{array}{l}{[41,42,58} \\
90,91,93- \\
95,140- \\
146]\end{array}$ & $\mathrm{C}$ \\
\hline
\end{tabular}




\begin{tabular}{|c|c|c|c|c|c|c|c|c|c|c|}
\hline m. $9011 \mathrm{C}>\mathrm{T}$ & $a \mathrm{~A} 162 \mathrm{~V}$ & LHON & 1 & 34 & 100 & bd & bd & $\mathrm{bd} / \mathrm{bd}$ & [147] & $\mathrm{N}$ \\
\hline m. $9016 A>G$ & $a \mathrm{I} 164 \mathrm{~V}$ & LHON & 1 & dorosły & 100 & bd & bd & $\mathrm{bd} / \mathrm{bd}$ & {$[148]$} & $\mathrm{N}$ \\
\hline m. $\underline{9025 \mathrm{G}>\mathrm{A}}$ & $a \mathrm{G} 167 \mathrm{~S}$ & Typu MILS, NARP & $2,1 \dagger$ & $0.2, \mathrm{bd}$ & 100 & bd & bd & $\mathrm{bd} / \mathrm{bd}$ & [33] & $\mathrm{N}$ \\
\hline m. $9029 A>G$ & $a \mathrm{H} 168 \mathrm{R}$ & Typu LHON & 1 & 38 & $95-99$ & obniżona & $\mathrm{bd}$ & $\begin{array}{l}\text { podwyższone/ } \\
\text { bd }\end{array}$ & [33] & $\mathrm{P}$ \\
\hline m. $9032 \mathrm{~T}>\mathrm{C}$ & $a \mathrm{~L} 169 \mathrm{P}$ & NARP & 1 & 16 & $70-90$ & obniżona & bd & $\begin{array}{l}\text { podwyższone/ } \\
\text { bd }\end{array}$ & [33] & $\mathrm{P}$ \\
\hline m. $9035 \mathrm{~T}>\mathrm{C}$ & $a \mathrm{~L} 170 \mathrm{P}$ & SCA & 21 & $4-48$ & $90-99$ & obniżona & $\mathrm{bd}$ & $\begin{array}{l}\text { podwyższone/ } \\
\text { bd }\end{array}$ & {$[35,104]$} & $\mathrm{C}$ \\
\hline m. $9055 \mathrm{G}>\mathrm{A}$ & $a \mathrm{~A} 177 \mathrm{~T}$ & Schizofrenia & 3 & $\mathrm{bd}$ & 100 & bd & bd & $\mathrm{bd} / \mathrm{bd}$ & [77] & $\mathrm{N}$ \\
\hline m.9058A>G & $a \mathrm{~T} 178 \mathrm{~A}$ & LVHT & 1 & $\mathrm{bd}$ & nd & bd & bd & $\mathrm{bd} / \mathrm{bd}$ & [81] & $\mathrm{N}$ \\
\hline $\mathrm{m} .9071 \mathrm{C}>\mathrm{T}$ & $a \mathrm{~S} 182 \mathrm{~L}$ & Schizofrenia & 1 & bd & 100 & bd & bd & $\mathrm{bd} / \mathrm{bd}$ & [76] & $\mathrm{N}$ \\
\hline m. $9094 \mathrm{C}>\mathrm{T}$ & $a \mathrm{~L} 190 \mathrm{~F}$ & Niewydolność jajników & 5 & 25 & bd & bd & $\mathrm{bd}$ & $\mathrm{bd} / \mathrm{bd}$ & [131] & $\mathrm{N}$ \\
\hline $\mathrm{m} .9101 \mathrm{~T}>\mathrm{C}$ & $a \mathrm{I} 192 \mathrm{~T}$ & LHON & 1 & 21 & 100 & obniżona & bd & $\mathrm{bd} / \mathrm{bd}$ & {$[43,111]$} & $\mathrm{P}$ \\
\hline m.9127delAT & $a \mathrm{I} 201 \mathrm{Pfs} X 2$ & NARP & 1 & 18 & $10-82$ & obniżona & bd & $\mathrm{bd} / \mathrm{bd}$ & [149] & $\mathrm{P}$ \\
\hline $\mathrm{m} .9134 \mathrm{~A}>\mathrm{G}$ & $a \mathrm{E} 203 \mathrm{G}$ & MS z kardiomiopatią & 1 & $\mathrm{bd}$ & $\mathrm{bd}$ & obniżona & bd & $\mathrm{bd} / \mathrm{bd}$ & [109] & $\mathrm{N}$ \\
\hline m.9139G $>A$ & $a \mathrm{~A} 205 \mathrm{~T}$ & LHON & 2 & 30,45 & bd & bd & bd & $\mathrm{bd} / \mathrm{bd}$ & [150] & $\mathrm{N}$ \\
\hline m. $9160 \mathrm{~T}>\mathrm{C}$ & $a \mathrm{Y} 212 \mathrm{H}$ & Schizofrenia & 1 & nd & 100 & bd & bd & $\mathrm{bd} / \mathrm{bd}$ & [77] & $\mathrm{N}$ \\
\hline$m .9176 T>G$ & $a \mathrm{~L} 217 \mathrm{R}$ & MILS & $6,3 \dagger$ & $3-42$ & 95-99 & obniżona & defektywny & $\begin{array}{l}\text { podwyższone/ } \\
\text { zaburzona }\end{array}$ & $\begin{array}{l}{[42,51,59,} \\
97,98, \\
151-155]\end{array}$ & $\mathrm{C}$ \\
\hline$m .9176 T>C$ & $a \mathrm{~L} 217 \mathrm{P}$ & $\begin{array}{l}\text { MILS, okresowe } \\
\text { porażenie, } \\
\text { CMT, HSP }\end{array}$ & $\begin{array}{l}19 \\
4 \dagger\end{array}$ & $1-59$ & $90-99$ & obniżona & defektywny & $\begin{array}{l}\text { podwyższone/ } \\
\text { zaburzona }\end{array}$ & $\begin{array}{l}{[42,51,56,} \\
97,98, \\
151-155]\end{array}$ & $\mathrm{C}$ \\
\hline$m .9185 T>C$ & $a \mathrm{~L} 220 \mathrm{P}$ & $\begin{array}{l}\text { Okresowe porażenie, } \\
\text { Ataksja, MILS, } \\
\text { CMT, MNS, SCA }\end{array}$ & $\begin{array}{l}61 \\
4 \dagger\end{array}$ & $2-58$ & 73-99 & obniżona & defektywny & bd/zaburzona & $\begin{array}{l}{[42,55,} \\
99-102, \\
104,156, \\
157]\end{array}$ & $\mathrm{C}$ \\
\hline$m .9191 T>C$ & $a \mathrm{~L} 222 \mathrm{P}$ & MILS & $1 \dagger$ & 2 & $90-94$ & obniżona & bd & bd/zaburzona & {$[55,100]$} & $\mathrm{P}$ \\
\hline m.9205delTA & $\begin{array}{l}a \text { eliminacja } \\
\text { kodonu } \\
\text { STOP }\end{array}$ & $\begin{array}{l}\text { Encefalopatia, } \\
\text { kwasica mleczanowa }\end{array}$ & $3,1 \dagger$ & $\begin{array}{l}\text { dorosły, } \\
\text { bd }\end{array}$ & $98-99$ & obniżona & bd & bd/zaburzona & $\begin{array}{l}{[32,115,} \\
158]\end{array}$ & $\mathrm{C}$ \\
\hline \multicolumn{11}{|c|}{$\begin{array}{l}\text { † - liczba pacjentów zmarłych; bd - brak danych; PG - patogenność: C - potwierdzona, P - podejrzana, N - nieznana; X - C-koniec białka, zapis } \\
\text { aT33HfsX32 oznacza zamianę reszty treoniny na resztę histydyny wraz z przesunięciem ramki odczytu prowadzącej do terminacji syntezy białka w } \\
\text { odległości } 32 \text { reszt aminokwasowych od miejsca zamienionej reszty aminokwasowej; MIDD - dziedziczna cukrzyca z głuchotą; LVHT - niescalony } \\
\text { mięsień lewej komory; MLTE-HS - padaczka skroniowa; MILS - dziedziczna podostra martwicza encefalo(mielo)patia; NARP - neurogenna miopatia } \\
\text { z ataksją i zwyrodnieniem barwnikowym siatkówki, LHON - dziedziczna neuropatia nerwu wzrokowego Lebera; FBSN - dwustronne obumarcie } \\
\text { prążkowia; MS - zespół metaboliczny; MLASA - miopatia z kwasicą mleczanową i anemią sideroblastyczną; CMT - Choroba Charcota-Mariego- } \\
\text { Tootha; HSP - wrodzona paraplegia spastyczna; MNS - choroba neuronu ruchowego; SCA - ataksja rdzeniowo-móżdżkowa. Mutacje, których brak } \\
\text { w bazie MITOMAP są podkreślone, a te dla których stworzyliśmy modele S. cerevisiae zaznaczono czcionką pochyłą. }\end{array}$} \\
\hline
\end{tabular}

\section{MUTACJE W GENACH KODUJĄCYCH PODJEDNOSTKI SYNTAZY ATP}

Mutacje w genach syntazy ATP prowadzą do bardzo ciężkich chorób, często kończących się śmiercią w pierwszym miesiącu czy roku życia. Spis tych chorób przedstawiono w tabeli 2. Zaburzają one funkcje enzymu, np. transport protonów przez domenę błonową, i/lub jego ilość z powodu nieefektywnego składania zmutowanej podjednostki, obniżonej stabilności enzymu czy zdolności do tworzenia struktur oligomerycznych $[6,63]$.

\section{MUTACJE W GENACH JĄDROWYCH}

Mutacje w pięciu jądrowych genach syntazy ATP, kodujących podjednostki $a, \delta$ i $\varepsilon$, oraz dwa białka będące czynnikami składania enzymu, ATP12 i TMEM70, zidentyfikowano $w$ różnych jednostkach chorobowych [6]. Opisano dwóch pacjentów z mutacją w genie ATP5A1 (podjednostka a), dwóch pacjentów z mutacjami w genie ATP5F1D (podjednostka $\delta$ ), po jednym pacjencie z mutacjami odpowiednio w ATPAF2 (ATP12) i ATP5E (podjednostka $\varepsilon$ ) oraz pięćdzie- sięciu pacjentów z mutacjami w genie TMEM70, w którym zidentyfikowano dotychczas dwanaście mutacji.

Pierwszą mutację jądrową znaleziono w genie ATPAF2, kodującym białko ATP12, niezbędne do składania domeny $\mathrm{F}_{1}, \mathrm{u}$ pacjenta $\mathrm{z}$ encefalopatią noworodkową o bardzo ostrym przebiegu [64]. Mutacja c.280T $>\mathrm{A} w$ obu allelach genu, prowadziła do zamiany reszty w pozycji 94 na resztę argininy (W94R), prawdopodobnie zaburzając oddziaływanie ATP12 z podjednostką $a$. Skutkuje to obniżeniem ilości kompleksów syntazy ATP. Badania na modelu drożdżowym pokazały, że białko z odpowiadającą białku ludzkiemu substytucją, Atp12-W103R, ma obniżoną rozpuszczalność i agreguje w macierzy mitochondrialnej, przez to jego funkcja jako czynnika składania podjednostki $a$ do domeny $F_{1}$ jest zaburzona [65].

U dwudziestu trzech pacjentów z noworodkową encefalo-kardiopatią, której towarzyszyła kwasica mleczanowa, zidentyfikowano mutację c.317-2A>G w genie TMEM70 [66]. W komórkach pacjentów wykazano obniżoną aktywność syntazy ATP, na skutek obniżonego poziomu kom- 
pletnego enzymu oraz akumulacji domeny $\mathrm{F}_{1}$. Na tej podstawie przypisano białku TMEM70 funkcję czynnika składania domeny $F_{1}$. Inna mutacja $w$ tym genie c.317-2A>G, opisana u trzydziestu pacjentów, występuje $\mathrm{w}$ miejscu wycięcia intronu przed trzecim egzonem i skutkuje brakiem syntezy białka TMEM70. U pojedynczych pacjentów zidentyfikowano $\mathrm{w}$ tym genie mutacje: c.316+1G>T, delecję g.2436-3789, delecję c.578_579delCA, c.336T>A, delecję c.211-450_317-568del, c.238C >T, podwójną mutację c.317-2A>G i c.118_119insGT, podwójną mutację c.317-2A>G i c.494G >A, podwójną mutację c.317-2A > G i c.628A > G, oraz c.535C>T. Wszystkie powodują syntezę skróconego białka TMEM70 z wyjątkiem ostatniej, która powoduje zamianę resztę histydyny 179 na histydynę.

Mutację c.35A>G w genie ATP5E, prowadzącą do zamiany reszty tyrozyny 12 na resztę cysteiny $\mathrm{w}$ podjednostce $\varepsilon$, znaleziono u pacjenta $\mathrm{z}$ kwasicą mleczanową i 3-metyloglutakonową (3-MGA), opóźnieniem umysłowym i zaburzeniami funkcji nerwów obwodowych [67]. Mutacja prowadzi do wadliwego składania enzymu. Obniżony poziom enzymu w komórkach pacjenta wywoływał spadek syntezy ATP.

Mutację c.985C>T w genie ATP5A1, prowadzącą do zamiany reszty argininy 329 na resztę cysteiny $\mathrm{w}$ podjednostce $a$, znaleziono u dwójki dzieci z noworodkową encefalopatią, które zmarły w pierwszym tygodniu życia [68]. Badania na fibroblastach pacjentów wykazały znaczące obniżenie zawartości enzymu, sugerując zaburzenia we wczesnych etapach jego biogenezy.

Dwie mutacje, c. $245 \mathrm{C}>\mathrm{T}$ oraz c.317T $>\mathrm{G}$, w genie ATP5F1D zamieniające odpowiednio resztę proliny $82 \mathrm{w}$ resztę leucyny i resztę waliny $106 \mathrm{w}$ resztę glicyny w podjednostce $\delta$ syntazy ATP, zidnetyfikowano u dwójki niespokrewnionych ze sobą dzieci. Pierwsza powodowała zaburzenia metaboliczne: kwasicę mleczanową i 3-metyloglutakonową (3-MGA) i wysokie stężenie amoniaku we krwi a druga encefalopatię [69]. Badania na fibroblastach pacjentów wykazały znaczny spadek zawartości enzymu, jego aktywności, a w konsekwecji akumulację metabolitów cyklu Krebsa.

\section{MUTACJE W GENACH \\ MITOCHONDRIALNYCH ATP8 I ATP6}

Geny ATP8 i ATP6 sąsiadują ze sobą w mtDNA w ten sposób, że koniec genu ATP8 (mtDNA 8366-8572) i początek genu ATP6 (mtDNA 8527-9207) nachodzą na siebie odcinkiem 46 nukleotydów, między pozycjami 8527 oraz 8572 mtDNA. Mutacje w tym obszarze zaburzają funkcję obu podjednostek. W literaturze opisano dotychczas 58 mutacji $\mathrm{w}$ tych genach, $36 \mathrm{z}$ nich znajduje się $\mathrm{w}$ bazie MITOMAP na liście mutacji potencjalnie patologicznych. Dzięki rozwojowi technik sekwencjonowania DNA i ich dostępności w diagnostyce, ich liczba ciągle wzrasta. Aktualna lista mutacji w genach ATP8 i ATP6 (sprawdzona w marcu 2018 r.), wraz z chorobami z jakimi są powiązane i danymi biochemicznymi dostępnymi obecnie, zawarta jest w tabeli 2. Pozycje zamienionych reszt aminokwasowych w białkach Atp8 i Atp6 na drożdżowym modelu struktury kanału protonów pokazano na rycinie 2 .
MUTACJE W GENIE KODUJACYM PODJEDNOSTKĘ 8

Dziesięć mutacji w podjednostce 8 zidentyfikowano u pacjentów z: padaczką (m.8502A>T - 8N46I, aż w 40 na 44 badanych przypadków) [70]; syndromami LVHT lub MIDD (m.8381A>G - 8T6A; polskie nazwy chorób znajdują się w legendzie do tabeli 2 [71,72]; padaczką, niewydolnością mięśniową lub chorobą neurologiczną z głuchotą $(\mathbf{m} .8393 \mathrm{C}>\mathrm{T}-8 \mathrm{P} 10 \mathrm{~S}$ [73], m.8403T $>\mathrm{C}-8 \mathrm{I} 13 \mathrm{~T}$ [42], i m.8411A > G - 8M16V [74], chorobą serca $(\mathbf{m} .8481 \mathrm{C}>\mathrm{T}$ 8P39L [75]; schizofrenią (m.8463A >G - 8Y33C, m.8510A$>$ G - 8K49E i m.8519G >A - 8E52K) [76,77]; oraz autyzmem (m.8472C>T - 8P36L) [78]. Wydaje się, że mutacje w genie kodującym tę podjednostkę prowadzą do chorób o słabiej wyrażonym fenotypie $\mathrm{w}$ porównianiu $\mathrm{z}$ mutacjami $\mathrm{w}$ genie kodującym podjednostkę $a$, co może wynikać z faktu, że jest ona zaangażowana w transport protonów w sposób pośredni. Za mniejszym znaczeniem tej podjednostki dla funkcji enzymu przemawia też niski poziom zachowania sekwencji białka w ewolucji.

\section{MUTACJE W OBSZARZE WSPÓLNYM DLA OBU PODJEDNOSTEK 8 I $a$}

Trzy mutacje w obszarze mtDNA wspólnym dla obu genów ATP8 i ATP6 (m.8528T >C $(8 \mathrm{~W} 55 \mathrm{R}+a \mathrm{M} 1 \mathrm{~T}), \mathbf{m} .8529 \mathrm{G}>\mathrm{A}$ $(8 \mathrm{~W} 55 \mathrm{STOP}+a \mathrm{M} 1 \mathrm{I}), \mathbf{m} .8558 \mathrm{C}>\mathrm{T}(8 \mathrm{P} 65 \mathrm{~S}+a \mathrm{~A} 11 \mathrm{~V}))$ zostały opisane u pacjentów z kardiomiopatią [44,79-81]. Czwarta mutacja w tym obszarze $(\mathbf{m} .8561 \mathrm{C}>\mathrm{G}-8 \mathrm{P} 66 \mathrm{~A}+a \mathrm{P} 12 \mathrm{R}) \mathrm{wy}-$ stępowała $\mathrm{w}$ mtDNA u pacjenta $\mathrm{z}$ ataksją, neuropatią obwodową i cukrzycą [82].

\section{MUTACJE W GENIE KODUJACYM PODJEDNOSTKĘ $a$}

W przeciwieństwie do podjednostki 8, sekwencja podjednostki $a$ jest w bardzo wysokim stopniu zachowana w ewolucji. 32 mutacje z 48 zmieniają zachowane w ewolucji reszty aminokwasów u kręgowców, 18 z nich jest zachowane także u drożdży.

Dwie mutacje w tej samej pozycji mtDNA opisano już u osiemdziesięciu ośmiu pacjentów z syndromem NARP lub MILS: m.8993T>G ( $a$ L156R) i m.8993T>C ( $a$ L156P) (Tab. 2). Pierwsza z nich, jednocześnie pierwsza opisana mutacja w podjednostce $a$ [83], prowadzi do ostrzejszego przebiegu chorób niż druga. Stopnień nasilenia objawów chorobowych zależy też od stopnia heteroplazmii mtDNA z mutacją $[84,85]$. Zaburza ona transport protonów przez domenę błonową enzymu, redukując jego aktywność nawet do 10\% aktywności w komórkach zdrowych. Zaproponowano też, że brak syntezy ATP przez zmutowany enzym wynika $\mathrm{z}$ nieefektywnego wykorzystania gradientu protonowego do fosforylacji ADP [37-41,8693]. Niektóre prace donoszą o zaburzeniu składania/ stabilności enzymu, ale badania na modelu drożdżowym pokazały, że zmutowany enzym jest stabilny [62]. $\mathrm{W}$ przeciwieństwie do reszty argininy, reszta proliny $\mathrm{w}$ pozycji 156 prowadzi do zaburzenia biogenezy enzymu oraz obniża zawartość kompletnych jego kompleksów w błonie, co powoduje obniżenie produkcji ATP do 70\% $[42,58,91,94,95]$. Obok deficytu w funkcjonowaniu systemu OXPHOS, obie mutacje powodowały wzrost produkcji ROS i zaburzenie morfologii mitochondriów. 

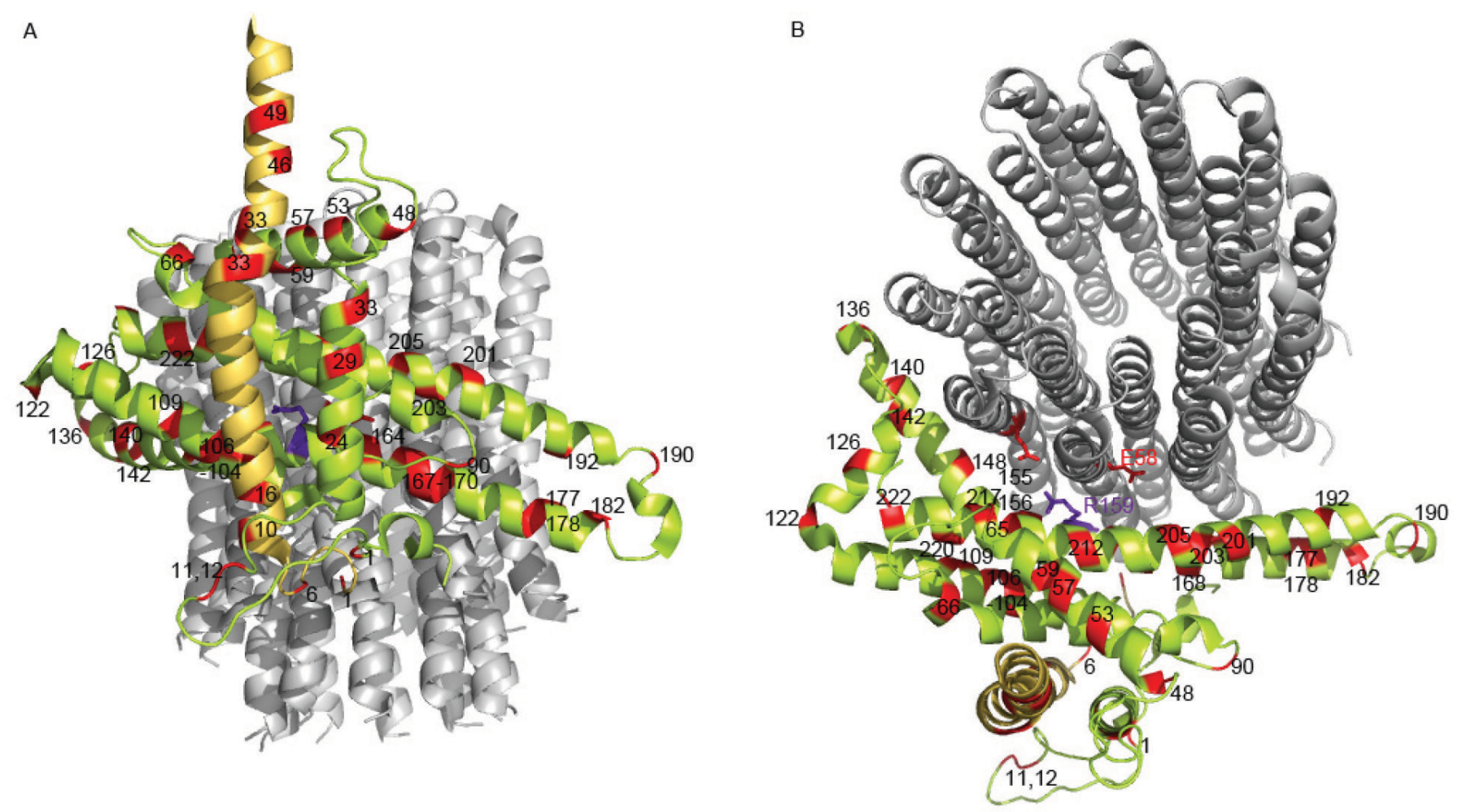

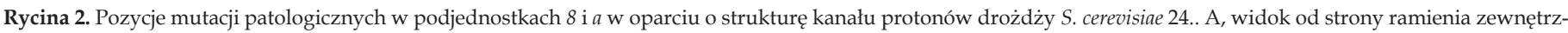

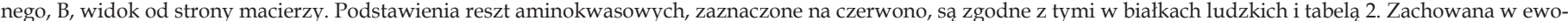

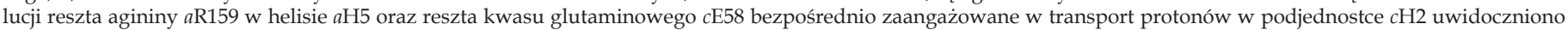
przez pokazanie ich łańcuchów bocznych odpowiednio w kolorach fioletowym i czerwonym. Rycina wykonana w programie Pymol.

Dwie mutacje $\mathrm{w}$ innej pozycji tego genu, powodują głównie MILS (Tab. 2): m.9176T >G (aL217R) i m.9176T >C $(a \mathrm{~L} 217 \mathrm{P})$. Zamiana reszty leucyny na resztę argininy całkowicie blokuje przyłączanie podjednostki $a$ do enzymu, w efekcie jest ona degradowana, a zawartość enzymu w mitochondriach jest śladowa [96]. Badania na modelu drożdżowym potwierdziły ten mechanizm choroby [59]. Druga mutacja obok MILS powoduje też chorobę Charcota-Mariego-Tootha, spastyczną paraplegię (osłabienie mięśni kończyn dolnych) i porażenia okresowe. Mutacja obniża poziom syntetyzowanego ATP do 75\%, zaburzając najprawdopodobniej funkcjonowanie syntazy ATP, obserwowano też niestabilność enzymu [97,98].

Najczęstsza (znaleziona u sześćdziesięciu jeden pacjentów) mutacja, m.9185T>C ( $a \mathrm{~L} 220 \mathrm{P})$, powoduje różnorodne choroby: MILS, chorobę neuronu ruchowego, Charcota-Mariego-Tootha, porażenie okresowe czy ataksję rdzeniowo-móżdżkową [42,99-102]. Badania biochemiczne, także na komórkach drożdży, wskazują, że zaburza ona funkcjonowanie enzymu obniżając $\mathrm{w}$ konsekwencji syntezę ATP do $50-90 \%[55]$.

U pojedynczych pacjentów z syndromami NARP lub MILS (Tab. 2) opisano osiem innych mutacji w genie podjednostki $a$ (m.8597T $>\mathrm{C}-a \mathrm{I} 24 \mathrm{~T}, \mathrm{~m} .8618$ ins, $\mathbf{m} .8839 \mathrm{G}>\mathrm{C}$ - $a$ A105P, m.8989G $>\mathrm{C}-a \mathrm{~A} 155 \mathrm{P}, \mathrm{m} .9025 \mathrm{G}>\mathrm{A}-a \mathrm{G} 167 \mathrm{~S}$, m.9032T>C - aL169P, m.9127delAT - aI201PfsX2 oraz m.9191T >C $-a$ L222P). Badania biochemiczne wskazują na patogenność niektórych z nich, np. m.8989G>C obniżała aktywność hydrolityczną syntazy ATP [103], m.9032T>C prowadziła do obniżenia oddychania oraz wzrostu ROS i potencjału na błonie wewnętrznej [33]. U podłoża chorób spowodowanych przez m.9191T>C leży drastyczne obniżenie przyłączania podjednostki $a$ do syntazy ATP [55].

U dwudziestu jeden pacjentów cierpiących na ataksję znaleziono mutację m.9035T>C (aL170P) [35,104]. W badaniach na cybrydach pokazano, że obok obniżenia aktywności hydrolitycznej syntazy ATP i poziomu komórkowego ATP o około $50 \%$, poziom ROS w komórce był podwyższony aż 5-7 razy. Inna mutacja, m.8611insC (aL29PfsX36), wywołuje ataksję, której towarzyszyła encefalopatia [105].

Mutacja m.8969G>A (aS148N) została znaleziona u dwóch pacjentów z syndromem MLASA [106] oraz z nefropatią [36]. Badania naszego zespołu pokazały, że reszta asparaginy $\mathrm{w}$ pozycji 148 bezpośrednio blokuje drogę wyjścia protonów po stronie macierzy, poprzez tworzenie wiązania wodorowego z kwasem glutaminowym w pozycji 145 (Skoczen N., praca przyjęta do druku w BBA-BIO), któremu przypisano funkcję bezpośredniego wiązania protonu w trakcie jego przejścia przez kanał po stronie macierzy [24]. Tym samym, jest to jedyna mutacja $\mathrm{w}$ genach syntazy ATP o tak dokładnie sprecyzowanym mechanizmie na poziomie molekularnym.

Mutacja m.8851T >C (aW109R) została zidentyfikowana u pacjentów z dwustronnym obumarciem prążkowia (FBSN) $[107,108]$. Badania na modelu drożdżowym wykazały pato- 
genny charakter mutacji m.8851T>C, która zaburza aktywności enzymu do poziomu $5 \%$ blokując transport protonów przez kanał [57]. Dwie mutacje powiązano z zespołem metabolicznym: m.9134A>G (aE203G) i m.8890A>G (aK122E), w przypadku pierwszej pacjent cierpiał również na kardiomiopatię [109,110].

Dziesięć mutacji w genie ATP6 powoduje dziedziczną neuropatię nerwu wzrokowego Lebera (LHON), jedyny zespół spowodowany mutacjami mtDNA, a dotyczący jednego tylko organu. Są to mutacje: (m.8668T $>\mathrm{C}$ (aW48R), $\mathbf{m . 8 6 8 4 C}>\mathrm{T} \quad(a \mathrm{~T} 53 \mathrm{I}), \mathbf{m . 8 6 9 7 G}>\mathrm{A} \quad(a \mathrm{M} 57 \mathrm{I}), \quad \mathbf{m . 8 8 3 6 A}>\mathrm{G}$ $(a \mathrm{M} 104 \mathrm{~V}), \mathbf{m} .8950 \mathrm{G}>\mathrm{A}(\mathrm{aV} 142 \mathrm{I}), \mathbf{m . 9 0 1 1 C}>\mathrm{T} \quad(a \mathrm{~A} 162 \mathrm{~V})$, m.9016A>G $(a \mathrm{I} 164 \mathrm{~V}), \quad$ m.9029A $>\mathrm{G}(a \mathrm{H} 168 \mathrm{R}), \mathrm{m.9101T}>\mathrm{C}$ (aI192T) i m.9139G>A (aA205T) (Tab. 2). Tylko dla dwóch (m.9029A>G i m.9101T>C) wykazano obniżoną aktywność systemu OXPHOS, podwyższony poziom ROS i potencjał na błonie wewnętrznej, ale mechanizm leżący u podłoża tych efektów nie jest znany [33,111].

Dwie mutacje wywołują chorobę neuromieśniową: m.8932C $>$ T $(a \mathrm{P} 136 \mathrm{~S})$ i m.8527A $>\mathrm{G}(a \mathrm{M} 1 \mathrm{~V})$ [112]. Co ciekawe, pierwszą z nich zidentyfikowano również w komórkach raka prostaty [113]. Badania na modelu drożdżowym tej mutacji wykazały, że obniża ona oddychanie komórkowe i aktywność syntazy ATP o 50\%, z dużym prawdopodobieństwem ma ona patologiczny charakter [61]. Ponadto wykazaliśmy jej znaczenie dla indukcji procesu apoptozy [114].

Delecja m.9205delTA eliminuje kodon STOP i została opisana u trzech pacjentów z kwasicą mleczanową i encefaliopatią [32,115]. W policistronowym mRNA kodującym ATP8 i ATP6 znajduje się również gen COX3, którego początek to pozycja m.9207. Wykazano, że mutacja zaburza dojrzewanie policitronowego mRNA, co prowadzi do obniżenia poziomu dojrzałych mRNA genów ATP6 i COX3. W konsekwencji ilość podjednostki $a \mathrm{~W}$ mitochondriach jest śladowa, a podjednostki COX3 obniżona o połowę. Mechanizm patologiczny tej mutacji oparty jest na zaburzeniu funkcji obu kompleksów łańcucha oddechowego: oksydazy cytochromu c i syntazy ATP.

Konsekwencje następujących mutacji, a więc ich patogenny charakter, nie są znane: $\mathbf{m . 8 7 1 9 G}>\mathbf{A}(a \mathrm{G} 65 \mathrm{X})$ i m.9058A>G ( $a \mathrm{~T} 178 \mathrm{~A})$ zidentyfikowane $\mathrm{u}$ pacjentów $\mathrm{z}$ zespołem niescalonego mięśnia lewej komory (LVHT) [81,116]. Dziesięć kolejnych: m.8701A>G (aT59A), m.8723G>A (aR66Q), $\mathbf{m . 8 7 9 4 C}>\mathrm{T} \quad(a \mathrm{H} 90 \mathrm{Y}), \quad \mathbf{m} .8843 \mathrm{~T}>\mathrm{C} \quad(a \mathrm{I} 106 \mathrm{~T})$, m.8902G $>$ A $(a \mathrm{~A} 126 \mathrm{~T}), \mathbf{m} .8945 \mathrm{~T}>\mathrm{C}(a \mathrm{M} 140 \mathrm{~T}), \mathbf{m} .9055 \mathrm{G}>\mathbf{A}$ $(a \mathrm{I} 177 \mathrm{~T}), \quad \mathrm{m} .9071 \mathrm{C}>\mathrm{T} \quad(a \mathrm{~S} 182 \mathrm{~L}), \quad \mathrm{m} .9094 \mathrm{C}>\mathrm{T} \quad(a \mathrm{~L} 190 \mathrm{~F}) \quad \mathrm{i}$ m.9160T >C (aY212H) znaleziono u pacjentów z autyzmem lub schizofrenią (Tab. 2).

\section{LOKALIZACJA PODSTAWIEŃ RESZT AMINOKWASOWYCH W PODJEDNOSTCE 8 I $a$}

W ostatnich latach, technikami mikroskopii elektronowej, uzyskano struktury syntazy ATP wołu Bos taurus oraz drożdży Yarrowia lipolytica i S. cerevisiae $[18,20,24]$. Skład podjednostkowy syntazy ATP drożdży nie różni się od enzymu kręgowców (Tab. 1) [21], również struk- tury enzymu u tych organizmów są bardzo podobne. Jedyną różnicą pomiędzy enzymem drożdży a człowieka jest liczba podjednostek $c \mathrm{w}$ pierścieniu (10 u drożdży, 8 u człowieka) (Ryc. 1) [117]. Wykorzystując model S. cerevisiae, zaznaczyliśmy $\mathrm{w}$ podjednistce 8 i a pozycje reszt aminokwasowych zamienionych przez mutacje $u$ pacjentów (Ryc. 2) oraz zaanalizowaliśmy ich potencjalne znaczenie dla struktury i funkcji enzymu, które opisujemy poniżej.

\section{PODSTAWIENIA RESZT AMINOKWASOWYCH W PODJEDNOSTCE $a$}

Helisa piąta podjednostki a (aH5) jest zakrzywiona wokół pierścienia podjednostek $c$, przez co obracający się pierścień znajduje się $\mathrm{w}$ bezpośrednim jej sąsiedztwie. Reszty polarnych aminokwasów helisy aH5 oraz helisy aH6 tworzą hydrofilowe kieszenie, drogę protonu po obu stronach błony [24]. Pięć mutacji zmieniających reszty hydrofobowych aminokwasów alaniny lub leucyny na resztę proliny znajduje się właśnie w helisie $a \mathrm{H} 5$, w pobliżu pełniącej ważną funkcję $\mathrm{W}$ transporcie protonu reszty argininy aR159 (aA105P, aA155P i aL156P), leżącej naprzeciwko wiążącego proton reszty kwasu glutaminowego (cE58), lub blisko $a \mathrm{H} 168 / a \mathrm{E} 203$ - dwóch reszt aminokwasowych prawdopodobnie wiążących proton $\mathrm{w}$ trakcie jego przejścia przez domenę błonową po stronie przestrzeni międzybłonowej (aL169P, aL170P). Te mutacje mogą zmieniać kształt helisy aH5. Mutacje w pozycjach 155 i 156, również położone blisko $a$ R159, mogą zaburzać mechanizm transportu protonu, wydłużając jego droge [28] lub zmieniając oddziaływanie $a$ R159 z cE58. W helisie $a \mathrm{H} 6$, mutacje $a \mathrm{~L} 217 \mathrm{P}, a \mathrm{~L} 220 \mathrm{P}$ i $a \mathrm{~L} 222 \mathrm{P}$ znajdują się na krawędzi kieszonki wyjścia protonu do macierzy. Ich poważne konsekwencje mogą wynikać ze zmiany położenia reszty kwasu asparaginowego w pozycji 224 (aD224), prawdopodobnie bezpośrednio zaangażowanej $\mathrm{w}$ transport protonu [24]. Podobnie, aP136S może zmieniać położenie pętli pomiędzy helisami $a \mathrm{H} 4$ i $a \mathrm{H} 5$ zaburzając drogę protonu $\mathrm{w}$ tym rejonie kanału.

Defekt w przyłączaniu podjednostki aL217R do syntazy ATP [59] spowodowany jest zamianą hydrofobowej reszty aminokwasowej na masywniejszą i naładowaną dodatnio, co utrudnia składanie tej silnie hydrofobowej podjednostki w błonie. Zamiana aL156R może blokować transport protonu [62], z powodu elektrostatycznej lub sferycznej przeszkody jaką jest reszta argininy, która może spowalniać rotację pierścienia. Zamiana aS148N, zlokalizowana w kieszeni wyjścia protonu do macierzy [36], może hamować transport protonu blokujacc bezpośrednio niezbędny do tego procesu kwas glutaminowy $a \mathrm{E} 145$, tworząc z nim wiązanie wodorowe (Skoczen, przyjęte do druku w BBA-BIO). Położenie $a \mathrm{H} 168 \mathrm{w}$ kanale po stronie macierzy [33] i zamiana jej reszty aminokwasowej na pozytywnie naładowaną resztę argininy może odcinać droge protonu z przestrzeni do pierścienia podjednostek c. Podobny efekt może powodować zamiana aW109R, blokując szczególnie drogę wejścia protonu z macierzy w trakcie hydrolizy ATP [57], co nie wyklucza hamowania wyjścia protonu do macierzy w trakcie syntezy ATP. Podobne konsekwencje może mieć zamiana $a \mathrm{~K} 122 \mathrm{E}$. 
Substytucje $a \mathrm{M} 140 \mathrm{~T}, a \mathrm{G} 167 \mathrm{~S}, a \mathrm{~A} 177 \mathrm{~T}, a \mathrm{I} 192 \mathrm{~T}, a \mathrm{~A} 205 \mathrm{~T} \mathrm{i}$ aY212H obniżają hydrofobowość powierzchni pomiędzy podjednostką $a$ i pierścieniem podjednostek $c$, co może być istotne dla rotacji pierścienia. Choć trudno przewidzieć konsekwencje na poziomie struktury zamiany hydrofobowych reszt aminokwasowych na hydrofilowe i obojętne (aI24T, aI106T, aA126T) lub odwrotnie (aT53I, $a \mathrm{~T} 59 \mathrm{~A}, a \mathrm{~T} 178 \mathrm{~A}, a \mathrm{~S} 182 \mathrm{~L})$ oraz substytucje, które zmieniają hydrofobowość (aM57I, $a$ M104V, aV142I, $a \mathrm{~A} 162 \mathrm{~V}, a \mathrm{I} 164 \mathrm{~V}$, $a \mathrm{~L} 190 \mathrm{~F})$, to lokalizacja reszt tych aminokwasów w obrębie helis kluczowych dla transportu protonów aH4-6 pozwala domniemywać o ich patogennym charakterze.

\section{PODSTAWIENIA RESZT AMINOKWASOWYCH W PODJEDNOSTCE 8}

Podjednostka 8 u drożdży ma strukturę helisy błonowej od strony N-końca i krótkiej helisy wystającej do macierzy $[20,24]$. Model syntazy ATP wołu jest pozbawiony C-końcowej struktury podjednostki 8 dlatego model drożdżowy został wykorzystany do analizy strukturalnej mutacji patologicznych [18]. Podjednostka 8 stabilizuje w błonie N-końcową połowę podjednostki $a$ [20]. Cztery mutacje znalezione u pacjentów $(8 \mathrm{~T} 6 \mathrm{~A}, 8 \mathrm{P} 10 \mathrm{~S}, 8 \mathrm{I} 13 \mathrm{~T}, 8 \mathrm{M} 16 \mathrm{~V})$ grupują się $\mathrm{w}$ $\mathrm{N}$-końcowym regionie helisy $8 \mathrm{H} 1 \mathrm{w}$ bliskim sąsiedztwie czwartej helisy podjednostki $a(a \mathrm{H} 4)$, co sugeruje, że mogą zaburzać stabilność oddziaływania pomiedzy tymi podjednostkami [20]. Pozostałe sześć mutacji (8Y33C, 8P36L, 8P39L, 8N46I, 8K49E, 8E52K) znajduje się w krótkiej helisie $8 \mathrm{H} 2$. Mogą nie być obojętne dla oddziaływania $\mathrm{z}$ błonową częścią ramienia zewnętrznego, a tym samym dla stabilności domeny błonowej enzymu. Mogą też wpływać pośrednio na transport protonów przez tę domenę.

\section{DIMERY SYNTAZY ATP A MORFOLOGIA MITOCHONDRIÓW}

Syntaza ATP występuje w błonie wewnętrznej mitochondriów $\mathrm{w}$ formie dimerów i oligomerów, które przyczyniają się do zakrzywiania błony i tworzenia grzebieni wewnątrz mitochondriów (Ryc. 1) [20,118-120]. W przypadku wielu mutacji obserwowano zaburzenie morfologii mitochondriów (Tab. 2), także takie defekty zaobserwowaliśmy w modelach drożdżowych niektórych mutacji [59]. Sugeruje to, że wtórnym efektem mutacji zaburzających składanie enzymu jest brak grzebieni, co jest kluczowe dla lokalizacji całego systemu OXPHOS, nie tylko syntazy ATP.

\section{WYKORZYSTANIE MITOCHONDRIALNYCH MUTANTÓW S. CEREVISIAE DO SELEKCJI ZWIĄZKÓW ODWRACAJACCYCH EFEKTY MUTACJI I BADANIA MECHANIZMÓW ICH DZIAŁANIA}

Obecnie choroby mitochondrialne są nieuleczalne a terapia polega na łagodzeniu objawów. Na przykład na modelu cybrydowym oraz komórkach od pacjenta z mutacją m.8993T>G pokazano, że zastosowanie związków antyoksydacyjnych poprawiało oddychanie komórkowe i syntezę ATP [40]. W oparciu o tę obserwację stosuje się często suplementację diety koenzymem Q10, N-acetylocysteiną, kwasem dihydrolipoinowym, karnityną, kreatyną czy witaminami, ale jej efekty są znikome [7].
Do selekcji aktywnych związków przywracających wzrost zależny od oddychania nasz zespół wykorzystał mutanta drożdżowego fmc1s, w którym zaburzone jest składanie domeny katalitycznej syntazy ATP. Jest to doskonały model defektów spowodowanych mutacjami w genach jądrowych ATPAF2 i TMEM70 [121-123]. W doświadczeniach użyliśmy, między innymi, bibliotekę Prestwick, związków o znanej cytotoksyczności, które są lub były testowane $\mathrm{w}$ badaniach klinicznych, mogą więc być dużo łatwiej wprowadzone do stosowania jako leki. Komórki defektywnego oddechowo mutanta fmc1 $1 \Delta$ wysiewano $\mathrm{w}$ gęstości $10^{8}$ na podłoże stałe z niefermentowalnym źródłem węgla, na powierzchni agaru umieszczano sterylne filtry, na które nanoszono związki w stężeniu $10 \mu \mathrm{M}$. Związki przywracające oddychanie powodowały wzrost komórek mutanta wokół filtra, często w formie pierścienia, co wskazywało jednocześnie na działanie związku w określonych stężeniach i na jego toksyczność w wysokich stężeniach. Wyizolowaliśmy dwa związki: chloroheksydynę $(\mathrm{CH})$ i pirytion sodu $(\mathrm{NaPT})$. $\mathrm{CH}$ poprawiała dwukrotnie zużycie tlenu i syntezę ATP w mutancie fmc1 $\Delta$ dzięki zwiększonej ilości kompleksów łańcucha oddechowego w błonie wewnętrznej. $\mathrm{CH}$ przywracała również wzrost oddechowy szczepów posiadających mutacje homologiczne do m.8993T $>\mathrm{G}$ i m.8851T $>\mathrm{C}$, ponadto wykazywała aktywność na modelu cybrydowym mutacji m.8993T>G w sposób zależny od stężenia. Wykazaliśmy, że w obecności $\mathrm{CH}$ poziom ekspresji genu QCR9, kodującego podjednostkę kompleksu cytochromów bc1, był znacząco podwyższony, co wskazuje, że poprawa ekspresji kompleksów OXPHOS w błonie wewnętrznej przez $\mathrm{CH}$ wymaga funkcji białka Qcr9 [121].

Obok komplementacji braku wzrostu oddechowego mutanta fmc1 $1 \Delta$, NaPT przywracał również wzrost zależny od oddychania mutantów m.9176T >G i m.8993T>G (Tab. 2). W celu poznania mechanizmu działania NaPT wykorzystaliśmy kolekcję mutantów heterozygotycznych drożdży by zidentyfikować, takie, które wykazywały podwyższoną wrażliwość na obecność związku w pożywce. Pozwala to zidentyfikować białka czy procesy komórkowe, poprzez które działa w komórce dany związek $[124,125]$. W obecności NaPT największą wrażliwość wykazały dwa mutanty $\mathrm{w}$ podjednostkach translokazy mitochondrialnej TIM23, tim174/TIM17 i tim234/TIM23 [126,127]. W dalszych badaniach wykazaliśmy, że NaPT znacząco indukuje tempo transportu białek do wewnętrznej błony mitochondrialnej przez komplex TIM23, w tym kompleksów systemu OXPHOS. Badania sugerują, że niewielka modulacja transportu do błony wewnętrznej mitochondriów może mieć efekt terapeutyczny, co więcej także w przypadku innych chorób, u podłoża których leżą dysfunkcje systemu OXPHOS. Jednocześnie pokazują one ogromny potencjał drożdży jako modelu badawczego nie tylko do badania mechanizmów chorób genetycznych ale też poszukiwania leków.

\section{PODSUMOWANIE I PERSPEKTYWY}

Zrozumienie mechanizmu chorób mitochondrialnych jest niezbędne do opracowania skutecznej terapii, której obecnie nie ma. Te spowodowane mutacjami $\mathrm{w}$ genach mi- 
tochondrialnych są szczególnie dużym wyzwaniem do badania, ze względu na heteroplazmię mtDNA, dziedziczenie matczyne czy wpływ tła genetycznego na ich przebieg, a więc i na efekty mutacji. Rozwój techniki konstruowania homoplazmatycznych linii komórkowych jak i wykorzystanie modeli drożdżowych, a także dostępność struktur syntazy ATP (szczególnie bardzo dokładnej struktury syntazy ATP drożdży) pozwala na badanie zaburzeń funkcji tego enzymu. Szczególnym zadaniem, jest wykorzystanie drożdży do poznania funkcji podjednostki 8 , która nie jest zbadana, i w której patogenne mutacje nie są rzadkością. Ciągle jesteśmy na początku drogi prowadzącej do poznania mechanizmów tych chorób, ale te badania dają nadzieję na terapię w przyszłości.

\section{PIŚMIENNICTWO}

1. Saraste M (1999) Oxidative phosphorylation at the fin de siecle. Science 283: 1488-1493

2. Lenaz G, Genova ML (2010) Structure and organization of mitochondrial respiratory complexes: a new understanding of an old subject. Antioxid Redox Signal 12: 961-1008

3. Boyer PD (1997) The ATP synthase - a splendid molecular machine. Annu Rev Biochem 66: 717-749

4. Chinnery PF (1993) Mitochondrial Disorders Overview. In: Pagon RA, Adam MP, Ardinger HH, et al (eds). GeneReviews(R), Seattle (WA)

5. Tuppen HA, Blakely EL, Turnbull DM, Taylor RW (2010) Mitochondrial DNA mutations and human disease. Biochim Biophys Acta 1797: 113-128

6. Hejzlarova K, Mracek T, Vrbacky M, Kaplanova V, Karbanova V, Nuskova H, Pecina P, Houstek J (2014) Nuclear genetic defects of mitochondrial ATP synthase. Physiol Res 63 Suppl 1: S57-71

7. Ng YS, Turnbull DM (2016) Mitochondrial disease: genetics and management. J Neurol 263: 179-191

8. Chinnery PF (2015) Mitochondrial disease in adults: what's old and what's new? EMBO Mol Med 7: 1503-1512

9. Stewart JB, Chinnery PF (2015) The dynamics of mitochondrial DNA heteroplasmy: implications for human health and disease. Nat Rev Genet 16: 530-542

10. Xu T, Pagadala V, Mueller DM (2015) Understanding structure, function, and mutations in the mitochondrial ATP synthase. Microb Cell 2: 105-125

11. Skladal D, Halliday J, Thorburn DR (2003) Minimum birth prevalence of mitochondrial respiratory chain disorders in children. Brain 126: 1905-1912

12. DiMauro S, Schon EA (2003) Mitochondrial respiratory-chain diseases. N Engl J Med 348: 2656-2668

13. Vafai SB, Mootha VK (2012) Mitochondrial disorders as windows into an ancient organelle. Nature 491: 374-383

14. Zeviani M, Carelli V (2007) Mitochondrial disorders. Curr Opin Neurol 20: 564-571

15. Wallace DC (2010) Mitochondrial DNA mutations in disease and aging. Environ Mol Mutagen 51: 440-450

16. Lott MT, Leipzig JN, Derbeneva O, Xie HM, Chalkia D, Sarmady M, Procaccio V, Wallace DC (2013) mtDNA Variation and Analysis Using MITOMAP and MITOMASTER. Curr Protoc Bioinformatics 44:1.23.126

17. Morales-Rios E, Montgomery MG, Leslie AG, Walker JE (2015) Structure of ATP synthase from Paracoccus denitrificans determined by $\mathrm{X}$ -ray crystallography at 4.0 A resolution. Proc Natl Acad Sci USA 112: $13231-13236$

18. Zhou A, Rohou A, Schep DG, Bason JV, Montgomery MG, Walker JE, Grigorieff N, Rubinstein JL (2015) Structure and conformational states of the bovine mitochondrial ATP synthase by cryo-EM. Elife 4: e10180
19. Allegretti M, Klusch N, Mills DJ, Vonck J, Kuhlbrandt W, Davies KM (2015) Horizontal membrane-intrinsic alpha-helices in the stator a-subunit of an F-type ATP synthase. Nature 521: 237-240

20. Hahn A, Parey K, Bublitz M, Mills DJ, Zickermann V, Vonck J, Kuhlbrandt W, Meier T (2016) Structure of a complete ATP synthase dimer reveals the molecular basis of inner mitochondrial membrane morphology. Mol Cell 63: 445-456

21. He J, Ford HC, Carroll J, Douglas C, Gonzales E, Ding S, Fearnley IM, Walker JE (2018) Assembly of the membrane domain of ATP synthase in human mitochondria. Proc Natl Acad Sci USA 115: 2988-2993

22. Parsons DF (1963) Mitochondrial Structure: Two types of subunits on negatively stained mitochondrial membranes. Science 140: 985-987

23. Strauss M, Hofhaus G, Schroder RR, Kuhlbrandt W (2008) Dimer ribbons of ATP synthase shape the inner mitochondrial membrane. EMBO J 27: 1154-1160

24. Guo H, Bueler SA, Rubinstein JL (2017) Atomic model for the dimeric FO region of mitochondrial ATP synthase. Science 358: 936-940

25. Vik SB, Antonio BJ (1994) A mechanism of proton translocation by F1F0 ATP synthases suggested by double mutants of the a subunit. J Biol Chem 269: 30364-30369

26. Junge W, Lill H, Engelbrecht S (1997) ATP synthase: an electrochemical transducer with rotatory mechanics. Trends Biochem Sci 22: 420423

27. Pogoryelov D, Krah A, Langer JD, Yildiz O, Faraldo-Gomez JD, Meier $\mathrm{T}$ (2010) Microscopic rotary mechanism of ion translocation in the $\mathrm{F}(\mathrm{o})$ complex of ATP synthases. Nat Chem Biol 6: 891-899

28. Mitome N, Ono S, Sato H, Suzuki T, Sone N, Yoshida M (2010) Essential arginine residue of the $\mathrm{F}(\mathrm{o})$-a subunit in $\mathrm{F}(\mathrm{o}) \mathrm{F}(1)$-ATP synthase has a role to prevent the proton shortcut without c-ring rotation in the $\mathrm{F}(\mathrm{o})$ proton channel. Biochem J 430: 171-177

29. Cai W, Fu Q, Zhou X, Qu J, Tong Y, Guan MX (2008) Mitochondrial variants may influence the phenotypic manifestation of Leber's hereditary optic neuropathy-associated ND4 G11778A mutation. J Genet Genomics 35: 649-655

30. Swalwell H, Blakely EL, Sutton R, Tonska K, Elstner M, He L, Taivassalo T, Burns DK, Turnbull DM, Haller RG, Davidson MM, Taylor RW (2008) A homoplasmic mtDNA variant can influence the phenotype of the pathogenic m.7472Cins MTTS1 mutation: are two mutations better than one? Eur J Hum Genet 16: 1265-1274

31. King MP, Attardi G (1989) Human cells lacking mtDNA: repopulation with exogenous mitochondria by complementation. Science 246: 500503

32. Hejzlarova K, Kaplanova V, Nuskova H, Kovarova N, Jesina P, Drahota Z, Mracek T, Seneca S, Houstek J (2015) Alteration of structure and function of ATP synthase and cytochrome c oxidase by lack of Fo-a and Cox3 subunits caused by mitochondrial DNA 9205delTA mutation. Biochem J 466: 601-611

33. Lopez-Gallardo E, Emperador S, Solano A, Llobet L, Martin-Navarro A, Lopez-Perez MJ, Briones P, Pineda M, Artuch R, Barraquer E, Jerico I, Ruiz-Pesini E, Montoya J (2014) Expanding the clinical phenotypes of MT-ATP6 mutations. Hum Mol Genet 23: 6191-6200

34. Blanco-Grau A, Bonaventura-Ibars I, Coll-Canti J, Melia MJ, Martinez R, Martinez-Gallo M, Andreu AL, Pinos T, Garcia-Arumi E (2013) Identification and biochemical characterization of the novel mutation m.8839G $>C$ in the mitochondrial ATP6 gene associated with NARP syndrome. Genes Brain Behav 12: 812-820

35. Sikorska M, Sandhu JK, Simon DK, Pathiraja V, Sodja C, Li Y, Ribecco-Lutkiewicz M, Lanthier P, Borowy-Borowski H, Upton A, Raha S, Pulst SM, Tarnopolsky MA (2009) Identification of ataxia-associated mtDNA mutations (m.4052T $>\mathrm{C}$ and m.9035T $>\mathrm{C}$ ) and evaluation of their pathogenicity in transmitochondrial cybrids. Muscle Nerve 40: 381-394

36. Wen S, Niedzwiecka K, Zhao W, Xu S, Liang S, Zhu X, Xie H, Tribouillard-Tanvier D, Giraud MF, Zeng C, Dautant A, Kucharczyk R, Liu Z, di Rago JP, Chen H (2016) Identification of G8969>A in mitochondrial ATP6 gene that severely compromises ATP synthase function in a patient with IgA nephropathy. Sci Rep 6: 36313 
37. Nijtmans LG, Henderson NS, Attardi G, Holt IJ (2001) Impaired ATP synthase assembly associated with a mutation in the human ATP synthase subunit 6 gene. J Biol Chem 276: 6755-6762

38. Carrozzo R, Rizza T, Stringaro A, Pierini R, Mormone E, Santorelli FM, Malorni W, Matarrese P (2004) Maternally-inherited Leigh syndrome-related mutations bolster mitochondrial-mediated apoptosis. J Neurochem 90: 490-501

39. Trounce I, Neill S, Wallace DC (1994) Cytoplasmic transfer of the mtDNA nt 8993 T-->G (ATP6) point mutation associated with Leigh syndrome into mtDNA-less cells demonstrates cosegregation with a decrease in state III respiration and ADP/O ratio. Proc Natl Acad Sci USA 91: 8334-8338

40. Mattiazzi M, Vijayvergiya C, Gajewski CD, DeVivo DC, Lenaz G, Wiedmann M, Manfredi G (2004) The mtDNA T8993G (NARP) mutation results in an impairment of oxidative phosphorylation that can be improved by antioxidants. Hum Mol Genet 13: 869-879

41. Pallotti F, Baracca A, Hernandez-Rosa E, Walker WF, Solaini G, Lenaz G, Melzi D'Eril GV, Dimauro S, Schon EA, Davidson MM (2004) Biochemical analysis of respiratory function in cybrid cell lines harbouring mitochondrial DNA mutations. Biochem J 384: 287-293

42. Aure K, Dubourg O, Jardel C, Clarysse L, Sternberg D, Fournier E, Laforet P, Streichenberger N, Petiot P, Gervais-Bernard H, Vial C, Bedat-Millet AL, Drouin-Garraud V, Bouillaud F, Vandier C, Fontaine B, Lombes A (2013) Episodic weakness due to mitochondrial DNA MT-ATP6/8 mutations. Neurology 81: 1810-1818

43. Majander A, Lamminen T, Juvonen V, Aula P, Nikoskelainen E, Savontaus ML, Wikstrom M (1997) Mutations in subunit 6 of the F1F0-ATP synthase cause two entirely different diseases. FEBS Lett 412: 351-354

44. Jonckheere AI, Hogeveen M, Nijtmans LG, van den Brand MA, Janssen AJ, Diepstra JH, van den Brandt FC, van den Heuvel LP, Hol FA, Hofste TG, Kapusta L, Dillmann U, Shamdeen MG, Smeitink JA, Rodenburg RJ (2008) A novel mitochondrial ATP8 gene mutation in a patient with apical hypertrophic cardiomyopathy and neuropathy. J Med Genet 45: 129-133

45. Steinmetz LM, Scharfe C, Deutschbauer AM, Mokranjac D, Herman ZS, Jones T, Chu AM, Giaever G, Prokisch H, Oefner PJ, Davis RW (2002) Systematic screen for human disease genes in yeast. Nat Genet 31: $400-404$

46. Reinders J, Zahedi RP, Pfanner N, Meisinger C, Sickmann A (2006) Toward the complete yeast mitochondrial proteome: multidimensional separation techniques for mitochondrial proteomics. J Proteome Res 5: 1543-1554

47. Prokisch H, Scharfe C, Camp DG, 2nd, Xiao W, David L, Andreoli C, Monroe ME, Moore RJ, Gritsenko MA, Kozany C, Hixson KK, Mottaz HM, Zischka H, Ueffing M, Herman ZS, Davis RW, Meitinger T, Oefner PJ, Smith RD, Steinmetz LM (2004) Integrative analysis of the mitochondrial proteome in yeast. PLoS Biol 2: e160

48. Pagliarini DJ, Calvo SE, Chang B, Sheth SA, Vafai SB, Ong SE, Walford GA, Sugiana C, Boneh A, Chen WK, Hill DE, Vidal M, Evans JG, Thorburn DR, Carr SA, Mootha VK (2008) A mitochondrial protein compendium elucidates complex I disease biology. Cell 134: 112-123

49. Rhee HW, Zou P, Udeshi ND, Martell JD, Mootha VK, Carr SA, Ting AY (2013) Proteomic mapping of mitochondria in living cells via spatially restricted enzymatic tagging. Science 339: 1328-1331

50. Bonnefoy N, Fox TD (2001) Genetic transformation of Saccharomyces cerevisiae mitochondria. Methods Cell Biol 65: 381-396

51. Okamoto K, Perlman PS, Butow RA (1998) The sorting of mitochondrial DNA and mitochondrial proteins in zygotes: preferential transmission of mitochondrial DNA to the medial bud. J Cell Biol 142: 613623

52. Baile MG, Claypool SM (2013) The power of yeast to model diseases of the powerhouse of the cell. Front Biosci (Landmark Ed) 18: 241-278

53. Lasserre JP, Dautant A, Aiyar RS, Kucharczyk R, Glatigny A, Tribouillard-Tanvier D, Rytka J, Blondel M, Skoczen N, Reynier P, Pitayu L, Rotig A, Delahodde A, Steinmetz LM, Dujardin G, Procaccio V, di Rago JP (2015) Yeast as a system for modeling mitochondrial disease mechanisms and discovering therapies. Dis Model Mech 8: 509-526
54. Bietenhader M, Martos A, Tetaud E, Aiyar RS, Sellem CH, Kucharczyk R, Clauder-Munster S, Giraud MF, Godard F, Salin B, Sagot I, Gagneur J, Dequard-Chablat M, Contamine V, Hermann-Le Denmat S, Sainsard-Chanet A, Steinmetz LM, di Rago JP (2012) Experimental relocation of the mitochondrial ATP9 gene to the nucleus reveals forces underlying mitochondrial genome evolution. PLoS Genet 8: e1002876

55. Kabala AM, Lasserre JP, Ackerman SH, di Rago JP, Kucharczyk R (2014) Defining the impact on yeast ATP synthase of two pathogenic human mitochondrial DNA mutations, T9185C and T9191C. Biochimie 100: 200-206

56. Kucharczyk R, Ezkurdia N, Couplan E, Procaccio V, Ackerman SH, Blondel M, di Rago JP (2010) Consequences of the pathogenic T9176C mutation of human mitochondrial DNA on yeast mitochondrial ATP synthase. Biochim Biophys Acta 1797: 1105-1112

57. Kucharczyk R, Giraud MF, Brethes D, Wysocka-Kapcinska M, Ezkurdia N, Salin B, Velours J, Camougrand N, Haraux F, di Rago JP (2013) Defining the pathogenesis of human mtDNA mutations using a yeast model: the case of T8851C. Int J Biochem Cell Biol 45: 130-140

58. Kucharczyk R, Rak M, di Rago JP (2009) Biochemical consequences in yeast of the human mitochondrial DNA 8993T $>C$ mutation in the ATPase6 gene found in NARP/MILS patients. Biochim Biophys Acta 1793: $817-824$

59. Kucharczyk R, Salin B, di Rago JP (2009) Introducing the human Leigh syndrome mutation T9176G into Saccharomyces cerevisiae mitochondrial DNA leads to severe defects in the incorporation of Atp6p into the ATP synthase and in the mitochondrial morphology. Hum Mol Genet 18: 2889-2898

60. Kucharczyk R, Zick M, Bietenhader M, Rak M, Couplan E, Blondel M, Caubet SD, di Rago JP (2009) Mitochondrial ATP synthase disorders: molecular mechanisms and the quest for curative therapeutic approaches. Biochim Biophys Acta 1793: 186-199

61. Niedzwiecka K, Kabala AM, Lasserre JP, Tribouillard-Tanvier D, Golik P, Dautant A, di Rago JP, Kucharczyk R (2016) Yeast models of mutations in the mitochondrial ATP6 gene found in human cancer cells. Mitochondrion 29: 7-17

62. Rak M, Tetaud E, Duvezin-Caubet S, Ezkurdia N, Bietenhader M, Rytka J, di Rago JP (2007) A yeast model of the neurogenic ataxia retinitis pigmentosa (NARP) T8993G mutation in the mitochondrial ATP synthase-6 gene. J Biol Chem 282: 34039-34047

63. Houstek J, Pickova A, Vojtiskova A, Mracek T, Pecina P, Jesina P (2006) Mitochondrial diseases and genetic defects of ATP synthase. Biochim Biophys Acta 1757: 1400-1405

64. De Meirleir L, Seneca S, Lissens W, De Clercq I, Eyskens F, Gerlo E, Smet J, Van Coster R (2004) Respiratory chain complex V deficiency due to a mutation in the assembly gene ATP12. J Med Genet 41: 120124

65. Meulemans A, Seneca S, Pribyl T, Smet J, Alderweirldt V, Waeytens A, Lissens W, Van Coster R, De Meirleir L, di Rago JP, Gatti DL, Ackerman SH (2010) Defining the pathogenesis of the human Atp12p W94R mutation using a Saccharomyces cerevisiae yeast model. J Biol Chem 285: 4099-4109

66. Cizkova A, Stranecky V, Mayr JA, Tesarova M, Havlickova V, Paul J, Ivanek R, Kuss AW, Hansikova H, Kaplanova V, Vrbacky M, Hartmannova H, Noskova L, Honzik T, Drahota Z, Magner M, Hejzlarova K, Sperl W, Zeman J, Houstek J, Kmoch S (2008) TMEM70 mutations cause isolated ATP synthase deficiency and neonatal mitochondrial encephalocardiomyopathy. Nat Genet 40: 1288-1290

67. Mayr JA, Havlickova V, Zimmermann F, Magler I, Kaplanova V, Jesina P, Pecinova A, Nuskova H, Koch J, Sperl W, Houstek J (2010) Mitochondrial ATP synthase deficiency due to a mutation in the ATP5E gene for the F1 epsilon subunit. Hum Mol Genet 19: 3430-3439

68. Jonckheere AI, Renkema GH, Bras M, van den Heuvel LP, Hoischen A, Gilissen C, Nabuurs SB, Huynen MA, de Vries MC, Smeitink JA, Rodenburg RJ (2013) A complex V ATP5A1 defect causes fatal neonatal mitochondrial encephalopathy. Brain 136: 1544-1554

69. Olahova M, Yoon WH, Thompson K, Jangam S, Fernandez L, Davidson JM, Kyle JE, Grove ME, Fisk DG, Kohler JN, et al. (2018) Biallelic mutations in ATP5F1D, which encodes a subunit of ATP synthase, cause a metabolic disorder. Am J Hum Genet 102: 494-504 
70. Gurses C, Azakli H, Alptekin A, Cakiris A, Abaci N, Arikan M, Kursun O, Gokyigit A, Ustek D (2014) Mitochondrial DNA profiling via genomic analysis in mesial temporal lobe epilepsy patients with hippocampal sclerosis. Gene 538: 323-327

71. Perucca-Lostanlen D, Narbonne H, Hernandez JB, Staccini P, Saunieres A, Paquis-Flucklinger V, Vialettes B, Desnuelle C (2000) Mitochondrial DNA variations in patients with maternally inherited diabetes and deafness syndrome. Biochem Biophys Res Commun 277: 771-775

72. Finsterer J, Stollberger C, Schubert B (2004) Acquired left ventricular hypertrabeculation/noncompaction in mitochondriopathy. Cardiology 102: 228-230

73. Galimberti CA, Diegoli M, Sartori I, Uggetti C, Brega A, Tartara A, Arbustini E (2006) Brain pseudoatrophy and mental regression on valproate and a mitochondrial DNA mutation. Neurology 67: 1715-1717

74. Mkaouar-Rebai E, Kammoun F, Chamkha I, Kammoun N, Hsairi I, Triki C, Fakhfakh F (2010) A de novo mutation in the adenosine triphosphatase (ATPase) 8 gene in a patient with mitochondrial disorder. J Child Neurol 25: 770-775

75. Tansel T, Pacal F, Ustek D (2014) A novel ATP8 gene mutation in an infant with tetralogy of Fallot. Cardiol Young 24: 531-533

76. Ueno H, Nishigaki Y, Kong QP, Fuku N, Kojima S, Iwata N, Ozaki N, Tanaka M (2009) Analysis of mitochondrial DNA variants in Japanese patients with schizophrenia. Mitochondrion 9: 385-393

77. Sequeira A, Rollins B, Magnan C, van Oven M, Baldi P, Myers RM, Barchas JD, Schatzberg AF, Watson SJ, Akil H, Bunney WE, Vawter MP (2015) Mitochondrial mutations in subjects with psychiatric disorders. PLoS One 10: e0127280

78. Piryaei F, Houshmand M, Aryani O, Dadgar S, Soheili ZS (2012) Investigation of the mitochondrial ATPase 6/8 and tRNA(Lys) genes mutations in Autism. Cell J 14: 98-101

79. Ware SM, El-Hassan N, Kahler SG, Zhang Q, Ma YW, Miller E, Wong B, Spicer RL, Craigen WJ, Kozel BA, Grange DK, Wong LJ (2009) Infantile cardiomyopathy caused by a mutation in the overlapping region of mitochondrial ATPase 6 and 8 genes. J Med Genet 46: 308-314

80. Imai A, Fujita S, Kishita Y, Kohda M, Tokuzawa Y, Hirata T, Mizuno Y, Harashima H, Nakaya A, Sakata Y, Takeda A, Mori M, Murayama K, Ohtake A, Okazaki Y (2016) Rapidly progressive infantile cardiomyopathy with mitochondrial respiratory chain complex $\mathrm{V}$ deficiency due to loss of ATPase 6 and 8 protein. Int J Cardiol 207: 203-205

81. Tang S, Batra A, Zhang Y, Ebenroth ES, Huang T (2010) Left ventricular noncompaction is associated with mutations in the mitochondrial genome. Mitochondrion 10: 350-357

82. Kytovuori L, Lipponen J, Rusanen H, Komulainen T, Martikainen MH, Majamaa K (2016) A novel mutation m.8561C>G in MT-ATP6/8 causing a mitochondrial syndrome with ataxia, peripheral neuropathy, diabetes mellitus, and hypergonadotropic hypogonadism. J Neurol 263: 2188-2195

83. Holt IJ, Harding AE, Petty RK, Morgan-Hughes JA (1990) A new mitochondrial disease associated with mitochondrial DNA heteroplasmy. Am J Hum Genet 46: 428-433

84. Jonckheere AI, Smeitink JA, Rodenburg RJ (2012) Mitochondrial ATP synthase: architecture, function and pathology. J Inherit Metab Dis 35: 211-225

85. Uziel G, Moroni I, Lamantea E, Fratta GM, Ciceri E, Carrara F, Zeviani M (1997) Mitochondrial disease associated with the T8993G mutation of the mitochondrial ATPase 6 gene: a clinical, biochemical, and molecular study in six families. J Neurol Neurosurg Psychiatry 63: 16-22

86. Tatuch Y, Christodoulou J, Feigenbaum A, Clarke JT, Wherret J, Smith C, Rudd N, Petrova-Benedict R, Robinson BH (1992) Heteroplasmic mtDNA mutation (T--G) at 8993 can cause Leigh disease when the percentage of abnormal mtDNA is high. Am J Hum Genet 50: 852-858

87. Houstek J, Klement P, Hermanska J, Houstkova H, Hansikova H, Van den Bogert C, Zeman J (1995) Altered properties of mitochondrial ATP-synthase in patients with a T-->G mutation in the ATPase 6 (subunit a) gene at position 8993 of mtDNA. Biochim Biophys Acta 1271: 349-357

88. Garcia JJ, Ogilvie I, Robinson BH, Capaldi RA (2000) Structure, functioning, and assembly of the ATP synthase in cells from patients with the T8993G mitochondrial DNA mutation. Comparison with the enzyme in Rho(0) cells completely lacking mtdna. J Biol Chem 275: 1107511081

89. Sgarbi G, Baracca A, Lenaz G, Valentino LM, Carelli V, Solaini G (2006) Inefficient coupling between proton transport and ATP synthesis may be the pathogenic mechanism for NARP and Leigh syndrome resulting from the T8993G mutation in mtDNA. Biochem J 395: 493-500

90. Baracca A, Sgarbi G, Mattiazzi M, Casalena G, Pagnotta E, Valentino ML, Moggio M, Lenaz G, Carelli V, Solaini G (2007) Biochemical phenotypes associated with the mitochondrial ATP6 gene mutations at nt8993. Biochim Biophys Acta 1767: 913-919

91. Morava E, Rodenburg RJ, Hol F, de Vries M, Janssen A, van den Heuvel L, Niitmans L, Smeitink J (2006) Clinical and biochemical characteristics in patients with a high mutant load of the mitochondrial T8993G/C mutations. Am J Med Genet A 140: 863-868

92. Cortes-Hernandez P, Vazquez-Memije ME, Garcia JJ (2007) ATP6 homoplasmic mutations inhibit and destabilize the human F1F0-ATP synthase without preventing enzyme assembly and oligomerization. J Biol Chem 282: 1051-1058

93. Vazquez-Memije ME, Shanske S, Santorelli FM, Kranz-Eble P, DeVivo DC, DiMauro S (1998) Comparative biochemical studies of ATPases in cells from patients with the T8993G or T8993C mitochondrial DNA mutations. J Inherit Metab Dis 21: 829-836

94. Vilarinho L, Barbot C, Carrozzo R, Calado E, Tessa A, Dionisi-Vici C, Guimaraes A, Santorelli FM (2001) Clinical and molecular findings in four new patients harbouring the mtDNA 8993T $>$ C mutation. J Inherit Metab Dis 24: 883-884

95. Craig K, Elliott HR, Keers SM, Lambert C, Pyle A, Graves TD, Woodward C, Sweeney MG, Davis MB, Hanna MG, Chinnery PF (2007) Episodic ataxia and hemiplegia caused by the $8993 \mathrm{~T}->\mathrm{C}$ mitochondrial DNA mutation. J Med Genet 44: 797-799

96. Carrozzo R, Tessa A, Vazquez-Memije ME, Piemonte F, Patrono C, Malandrini A, Dionisi-Vici C, Vilarinho L, Villanova M, Schagger H, Federico A, Bertini E, Santorelli FM (2001) The T9176G mtDNA mutation severely affects ATP production and results in Leigh syndrome. Neurology 56: 687-690

97. Verny C, Guegen N, Desquiret V, Chevrollier A, Prundean A, Dubas F, Cassereau J, Ferre M, Amati-Bonneau P, Bonneau D, Reynier P, Procaccio V (2011) Hereditary spastic paraplegia-like disorder due to a mitochondrial ATP6 gene point mutation. Mitochondrion 11: 70-75

98. Jacobs LJ, de Coo IF, Nijland JG, Galjaard RJ, Los FJ, Schoonderwoerd K, Niermeijer MF, Geraedts JP, Scholte HR, Smeets HJ (2005) Transmission and prenatal diagnosis of the T9176C mitochondrial DNA mutation. Mol Hum Reprod 11: 223-228

99. Castagna AE, Addis J, McInnes RR, Clarke JT, Ashby P, Blaser S, Robinson $\mathrm{BH}$ (2007) Late onset Leigh syndrome and ataxia due to a $\mathrm{T}$ to $\mathrm{C}$ mutation at bp 9,185 of mitochondrial DNA. Am J Med Genet A 143A: 808-816

100.Moslemi AR, Darin N, Tulinius M, Oldfors A, Holme E (2005) Two new mutations in the MTATP6 gene associated with Leigh syndrome. Neuropediatrics 36: 314-318

101.Pitceathly RD, Murphy SM, Cottenie E, Chalasani A, Sweeney MG, Woodward C, Mudanohwo EE, Hargreaves I, Heales S, Land J, Holton JL, Houlden H, Blake J, Champion M, Flinter F, Robb SA, Page R, Rose M, Palace J, Crowe C, Longman C, Lunn MP, Rahman S, Reilly MM, Hanna MG (2012) Genetic dysfunction of MT-ATP6 causes axonal Charcot-Marie-Tooth disease. Neurology 79: 1145-1154

102. Childs AM, Hutchin T, Pysden K, Highet L, Bamford J, Livingston J, Crow YJ (2007) Variable phenotype including Leigh syndrome with a 9185T>C mutation in the MTATP6 gene. Neuropediatrics 38: 313-316

103. Duno M, Wibrand F, Baggesen K, Rosenberg T, Kjaer N, Frederiksen AL (2013) A novel mitochondrial mutation m.8989G $>$ C associated with neuropathy, ataxia, retinitis pigmentosa - the NARP syndrome. Gene 515: 372-375

104.Pfeffer G, Blakely EL, Alston CL, Hassani A, Boggild M, Horvath R, Samuels DC, Taylor RW, Chinnery PF (2012) Adult-onset spinocerebellar ataxia syndromes due to MTATP6 mutations. J Neurol Neurosurg Psychiatry 83: 883-886 
105. Jackson CB, Hahn D, Schroter B, Richter U, Battersby BJ, Schmitt-Mechelke T, Marttinen P, Nuoffer JM, Schaller A (2017) A novel mitochondrial ATP6 frameshift mutation causing isolated complex V deficiency, ataxia and encephalomyopathy. Eur J Med Genet 60: 345-351

106. Burrage LC, Tang S, Wang J, Donti TR, Walkiewicz M, Luchak JM, Chen LC, Schmitt ES, Niu Z, Erana R, Hunter JV, Graham BH, Wong LJ, Scaglia F (2014) Mitochondrial myopathy, lactic acidosis, and sideroblastic anemia (MLASA) plus associated with a novel de novo mutation $(\mathrm{m} .8969 \mathrm{G}>\mathrm{A})$ in the mitochondrial encoded ATP6 gene. Mol Genet Metab 113: 207-212

107.Honzik T, Tesarova M, Vinsova K, Hansikova H, Magner M, Kratochvilova H, Zamecnik J, Zeman J, Jesina P (2013) Different laboratory and muscle biopsy findings in a family with an m.8851T $>$ C mutation in the mitochondrial MTATP6 gene. Mol Genet Metab 108: 102-105

108. De Meirleir L, Seneca S, Lissens W, Schoentjes E, Desprechins B (1995) Bilateral striatal necrosis with a novel point mutation in the mitochondrial ATPase 6 gene. Pediatr Neurol 13: 242-246

109.Honzik T, Tesarova M, Magner M, Mayr J, Jesina P, Vesela K, Wenchich L, Szentivanyi K, Hansikova H, Sperl W, Zeman J (2012) Neonatal onset of mitochondrial disorders in 129 patients: clinical and laboratory characteristics and a new approach to diagnosis. J Inherit Metab Dis 35: 749-759

110. Ye W, Chen S, Jin S, Lu J (2013) A novel heteroplasmic mitochondrial DNA mutation, A8890G, in a patient with juvenileonset metabolic syndrome: a case report. Mol Med Rep 8: 1060-1066

111.Lamminen T, Majander A, Juvonen V, Wikstrom M, Aula P, Nikoskelainen E, Savontous ML (1995) A mitochondrial mutation at nt 9101 in the ATP synthase 6 gene associated with deficient oxidative phosphorylation in a family with Leber hereditary optic neuroretinopathy. Am J Hum Genet 56: 1238-1240

112.Felhi R, Mkaouar-Rebai E, Sfaihi-Ben Mansour L, Alila-Fersi O, Tabebi M, Ben Rhouma B, Ammar M, Keskes L, Hachicha M, Fakhfakh F (2016) Mutational analysis in patients with neuromuscular disorders: Detection of mitochondrial deletion and double mutations in the MT-ATP6 gene. Biochem Biophys Res Commun 473: 61-66

113.Petros JA, Baumann AK, Ruiz-Pesini E, Amin MB, Sun CQ, Hall J, Lim S, Issa MM, Flanders WD, Hosseini SH, Marshall FF, Wallace DC (2005) mtDNA mutations increase tumorigenicity in prostate cancer. Proc Natl Acad Sci USA 102: 719-724

114.Niedzwiecka K, Tisi R, Penna S, Lichocka M, Plochocka D, Kucharczyk R (2018) Two mutations in mitochondrial ATP6 gene of ATP synthase, related to human cancer, affect ROS, calcium homeostasis and mitochondrial permeability transition in yeast. Biochim Biophys Acta 1865: 117-131

115. Jesina P, Tesarova M, Fornuskova D, Vojtiskova A, Pecina P, Kaplanova V, Hansikova H, Zeman J, Houstek J (2004) Diminished synthesis of subunit a (ATP6) and altered function of ATP synthase and cytochrome c oxidase due to the mtDNA 2 bp microdeletion of TA at positions 9205 and 9206. Biochem J 383: 561-571

116. Tang S, Wang J, Zhang VW, Li FY, Landsverk M, Cui H, Truong CK, Wang G, Chen LC, Graham B, Scaglia F, Schmitt ES, Craigen WJ, Wong LJ (2013) Transition to next generation analysis of the whole mitochondrial genome: a summary of molecular defects. Hum Mutat 34: 882-893

117.Watt IN, Montgomery MG, Runswick MJ, Leslie AG, Walker JE (2010) Bioenergetic cost of making an adenosine triphosphate molecule in animal mitochondria. Proc Natl Acad Sci U S A 107: 16823-16827

118.Schagger H, Pfeiffer K (2000) Supercomplexes in the respiratory chains of yeast and mammalian mitochondria. EMBO J 19: 1777-1783

119. Paumard P, Vaillier J, Coulary B, Schaeffer J, Soubannier V, Mueller DM, Brethes D, di Rago JP, Velours J (2002) The ATP synthase is involved in generating mitochondrial cristae morphology. EMBO J 21: $221-230$

120.Davies KM, Daum B, Gold VA, Muhleip AW, Brandt T, Blum TB, Mills DJ, Kuhlbrandt W (2014) Visualization of ATP synthase dimers in mitochondria by electron cryo-tomography. J Vis Exp: 51228

121. Couplan E, Aiyar RS, Kucharczyk R, Kabala A, Ezkurdia N, Gagneur J, St Onge RP, Salin B, Soubigou F, Le Cann M, Steinmetz LM, di Rago
JP, Blondel M (2011) A yeast-based assay identifies drugs active against human mitochondrial disorders. Proc Natl Acad Sci USA 108: 11989-11994

122. Aiyar RS, Bohnert M, Duvezin-Caubet S, Voisset C, Gagneur J, Fritsch ES, Couplan E, von der Malsburg K, Funaya C, Soubigou F, Courtin F, Suresh S, Kucharczyk R, Evrard J, Antony C, St Onge RP, Blondel M, di Rago JP, van der Laan M, Steinmetz LM (2014) Mitochondrial protein sorting as a therapeutic target for ATP synthase disorders. Nat Commun 5: 5585

123. Lefebvre-Legendre L, Vaillier J, Benabdelhak H, Velours J, Slonimski PP, di Rago JP (2001) Identification of a nuclear gene (FMC1) required for the assembly/stability of yeast mitochondrial F(1)-ATPase in heat stress conditions. J Biol Chem 276: 6789-6796

124.Hoon S, Smith AM, Wallace IM, Suresh S, Miranda M, Fung E, Proctor M, Shokat KM, Zhang C, Davis RW, Giaever G, St Onge RP, Nislow C (2008) An integrated platform of genomic assays reveals small-molecule bioactivities. Nat Chem Biol 4: 498-506

125. Ho CH, Magtanong L, Barker SL, Gresham D, Nishimura S, Natarajan P, Koh JL, Porter J, Gray CA, Andersen RJ, Giaever G, Nislow C, Andrews B, Botstein D, Graham TR, Yoshida M, Boone C (2009) A molecular barcoded yeast ORF library enables mode-of-action analysis of bioactive compounds. Nat Biotechnol 27: 369-377

126. Hoogenraad NJ, Ward LA, Ryan MT (2002) Import and assembly of proteins into mitochondria of mammalian cells. Biochim Biophys Acta 1592: 97-105

127. Meier S, Neupert W, Herrmann JM (2005) Conserved N-terminal negative charges in the Tim17 subunit of the TIM23 translocase play a critical role in the import of preproteins into mitochondria. J Biol Chem 280: 7777-7785

128. Tsai JD, Liu CS, Tsao TF, Sheu JN (2012) A novel mitochondrial DNA $8597 \mathrm{~T}>\mathrm{C}$ mutation of Leigh syndrome: report of one case. Pediatr Neonatol 53: 60-62

129. Lopez-Gallardo E, Solano A, Herrero-Martin MD, Martinez-Romero I, Castano-Perez MD, Andreu AL, Herrera A, Lopez-Perez MJ, Ruiz-Pesini E, Montoya J (2009) NARP syndrome in a patient harbouring an insertion in the MT-ATP6 gene that results in a truncated protein. J Med Genet 46: 64-67

130.Kumar M, Tanwar M, Saxena R, Sharma P, Dada R (2010) Identification of novel mitochondrial mutations in Leber's hereditary optic neuropathy. Mol Vis 16: 782-792

131.Venkatesh S, Kumar M, Sharma A, Kriplani A, Ammini AC, Talwar P, Agarwal A, Dada R (2010) Oxidative stress and ATPase6 mutation is associated with primary ovarian insufficiency. Arch Gynecol Obstet 282: 313-318

132. Abu-Amero KK, Bosley TM (2006) Mitochondrial abnormalities in patients with LHON-like optic neuropathies. Invest Ophthalmol Vis Sci 47: 4211-4220

133. Abu-Amero KK, Bosley TM (2005) Detection of mitochondrial respiratory dysfunction in circulating lymphocytes using resazurin. Arch Pathol Lab Med 129: 1295-1298

134. Ciafaloni E, Santorelli FM, Shanske S, Deonna T, Roulet E, Janzer C, Pescia G, DiMauro S (1993) Maternally inherited Leigh syndrome. J Pediatr 122: 419-422

135.Puddu P, Barboni P, Mantovani V, Montagna P, Cerullo A, Bragliani M, Molinotti C, Caramazza R (1993) Retinitis pigmentosa, ataxia, and mental retardation associated with mitochondrial DNA mutation in an Italian family. Br J Ophthalmol 77: 84-88

136. Rojo A, Campos Y, Sanchez JM, Bonaventura I, Aguilar M, Garcia A, Gonzalez L, Rey MJ, Arenas J, Olive M, Ferrer I (2006) NARP-MILS syndrome caused by 8993 T>G mitochondrial DNA mutation: a clinical, genetic and neuropathological study. Acta Neuropathol 111: 610616

137. Baracca A, Barogi S, Carelli V, Lenaz G, Solaini G (2000) Catalytic activities of mitochondrial ATP synthase in patients with mitochondrial DNA T8993G mutation in the ATPase 6 gene encoding subunit a. J Biol Chem 275: 4177-4182 
138.Sakai Y, Kaga K, Kodama K, Higuchi A, Miyamoto J (2004) Hearing evaluation in two sisters with a T8993G point mutation of mitochondrial DNA. Int J Pediatr Otorhinolaryngol 68: 1115-1119

139. Enns GM, Bai RK, Beck AE, Wong LJ (2006) Molecular-clinical correlations in a family with variable tissue mitochondrial DNA T8993G mutant load. Mol Genet Metab 88: 364-371

140. de Vries DD, van Engelen BG, Gabreels FJ, Ruitenbeek W, van Oost BA (1993) A second missense mutation in the mitochondrial ATPase 6 gene in Leigh's syndrome. Ann Neurol 34: 410-412

141.Fujii T, Hattori H, Higuchi Y, Tsuji M, Mitsuyoshi I (1998) Phenotypic differences between T-->C and T-->G mutations at nt 8993 of mitochondrial DNA in Leigh syndrome. Pediatr Neurol 18: 275-277

142. Hurvitz H, Naveh Y, Shoseyov D, Klar A, Shaag A, Elpeleg O (2002) Transmission of the mitochondrial $\mathrm{t} 8993 \mathrm{c}$ mutation in a new family. Am J Med Genet 111: 446-447

143. Kara B, Arikan M, Maras H, Abaci N, Cakiris A, Ustek D (2012) Whole mitochondrial genome analysis of a family with NARP/MILS caused by m.8993T>C mutation in the MT-ATP6 gene. Mol Genet Metab 107: 389-393

144. Martikainen MH, Gorman GS, Goldsmith P, Burn DJ, Turnbull DM, Schaefer AM (2015) Adult-onset myoclonus ataxia associated with the mitochondrial m.8993T>C "NARP" mutation. Mov Disord 30: 1432-1433

145.Santorelli FM, Shanske S, Jain KD, Tick D, Schon EA, DiMauro S (1994) A T-->C mutation at nt 8993 of mitochondrial DNA in a child with Leigh syndrome. Neurology 44: 972-974

146. Debray FG, Lambert M, Lortie A, Vanasse M, Mitchell GA (2007) Long-term outcome of Leigh syndrome caused by the NARP-T8993C mtDNA mutation. Am J Med Genet A 143A: 2046-2051

147.Shidara K, Wakakura M (2012) Leber's hereditary optic neuropathy with the 3434, 9011 mitochondrial DNA point mutation. Jpn J Ophthalmol 56: 175-180

148. Povalko N, Zakharova E, Rudenskaia G, Akita Y, Hirata K, Toyojiro M, Koga Y (2005) A new sequence variant in mitochondrial DNA associated with high penetrance of Russian Leber hereditary optic neuropathy. Mitochondrion 5: 194-199
149. Mordel P, Schaeffer S, Dupas Q, Laville MA, Gerard M, Chapon F, Allouche S (2017) A 2 bp deletion in the mitochondrial ATP 6 gene responsible for the NARP (neuropathy, ataxia, and retinitis pigmentosa) syndrome. Biochem Biophys Res Commun 494: 133-137

150.La Morgia C, Achilli A, Iommarini L, Barboni P, Pala M, Olivieri A, Zanna C, Vidoni S, Tonon C, Lodi R, Vetrugno R, Mostacci B, Liguori R, Carroccia R, Montagna P, Rugolo M, Torroni A, Carelli V (2008) Rare mtDNA variants in Leber hereditary optic neuropathy families with recurrence of myoclonus. Neurology 70: 762-770

151.Dionisi-Vici C, Seneca S, Zeviani M, Fariello G, Rimoldi M, Bertini E, De Meirleir L (1998) Fulminant Leigh syndrome and sudden unexpected death in a family with the T9176C mutation of the mitochondrial ATPase 6 gene. J Inherit Metab Dis 21: 2-8

152. Thyagarajan D, Shanske S, Vazquez-Memije M, De Vivo D, DiMauro $S$ (1995) A novel mitochondrial ATPase 6 point mutation in familial bilateral striatal necrosis. Ann Neurol 38: 468-472

153. Makino M, Horai S, Goto Y, Nonaka I (1998) Confirmation that a T-to-C mutation at 9176 in mitochondrial DNA is an additional candidate mutation for Leigh's syndrome. Neuromuscul Disord 8: 149-151

154. Ronchi D, Bordoni A, Cosi A, Rizzuti M, Fassone E, Di Fonzo A, Servida M, Sciacco M, Collotta M, Ronzoni M, Lucchini V, Mattioli M, Moggio M, Bresolin N, Corti S, Comi GP (2011) Unusual adult-onset Leigh syndrome presentation due to the mitochondrial m.9176T $>\mathrm{C}$ mutation. Biochem Biophys Res Commun 412: 245-248

155.Synofzik M, Schicks J, Wilhelm C, Bornemann A, Schols L (2012) Charcot-Marie-Tooth hereditary neuropathy due to a mitochondrial ATP6 mutation. Eur J Neurol 19: e114-116

156.Saneto RP, Singh KK (2010) Illness-induced exacerbation of Leigh syndrome in a patient with the MTATP6 mutation, m. 9185 T>C. Mitochondrion 10: 567-572

157. Brum M, Semedo C, Guerreiro R, Pinto Marques J (2014) Motor Neuron Syndrome as a New Phenotypic Manifestation of Mutation 9185T>C in Gene MTATP6. Case Rep Neurol Med 2014: 701761

158.Seneca S, Abramowicz M, Lissens W, Muller MF, Vamos E, de Meirleir L (1996) A mitochondrial DNA microdeletion in a newborn girl with transient lactic acidosis. J Inherit Metab Dis 19: 115-118

\title{
Molecular bases of diseases caused by mutations in genes encoding subunits of ATP synthase
}

\author{
Emilia Baranowska, Joanna Rytka, Róża Kucharczyk ${ }^{\bowtie}$
}

Department of Genetics, Instytute of Biochemistry and Biophysics PAS, 5A Pawinskiego St., 02-106 Warsaw, Poland

e-mail: roza@ibb.waw.pl

Key words: ATP synthase, ATP12 gene, ATP6 gene, ATP8 gene, mitochondrial diseases

\begin{abstract}
ATP synthase is the last enzyme of the OXPHOS system synthesizing ATP. Mutations in either mitochondrial or nuclear genes encoding subunits of this enzyme (17 polypeptides) cause neurodegenerative diseases. The ATP synthase subunits 8 (ATP8, alias A6L) and $a$ (ATP6) are encoded by the MT-ATP8 and MT-ATP6 mitochondrial genes, respectively. 17 diseases associated mutations were identified in five nuclear genes coding for subunits of this enzyme. 58 mutations were described in the MT-ATP6 and MT-ATP8 genes, among them 36 were deposited in MITOMAP database. For most of them neither their pathogenic character nor the mechanisms are known. This review summarizes what is known about the molecular basis of the ATP synthase deficiencies. We review the mutations in the ATP synthase genes as well as biochemical data obtained from studies of patient's cells and cybrid or yeast models. We include yeast research about drugs selection and their mechanism of action. Moreover we position the mutations into a recently published structural model of the Fo complex and discuss their structural/functional consequences.
\end{abstract}

